DANMARKS GEOLOGISKE UNDERS $\emptyset$ GELSE · SERIE A · NR. 15 MILJØMINISTERIET · Geological Survey of Denmark

\title{
The diagenesis of the Lower Triassic Bunter Sandstone Formation, Onshore Denmark
}

BY

STANLEY FINE



I kommission hos C. A. Reitzels forlag · København 1986 


\section{The diagenesis of the Lower Triassic Bunter Sandstone Formation, Onshore Denmark}

BY

STANLEY FINE

I kommission hos C. A. Reitzels forlag · København 1986 
Key words:

Bunter, Sandstone, Diagenesis, Triassic, Denmark

with 5 plates

DGU Serie A nr. 15

ISBN 87-421-0748-2

ISSN $0901-0270$

Oplag: 1200

Tryk: AiO Tryk as, Odense

Tegning: Eva Melskens og Gitte Nicolaisen

Dato: 1986-12-01

Stanley Fine, present address:

Mærsk Olie og Gas A/S

Rønnegade 2

2100 København $\varnothing$

Redaktion: Leif Banke Rasmussen

(C) Danmarks Geologiske Undersøgelse,

Thoravej 31, DK-2400 København NV 


\section{Contents}

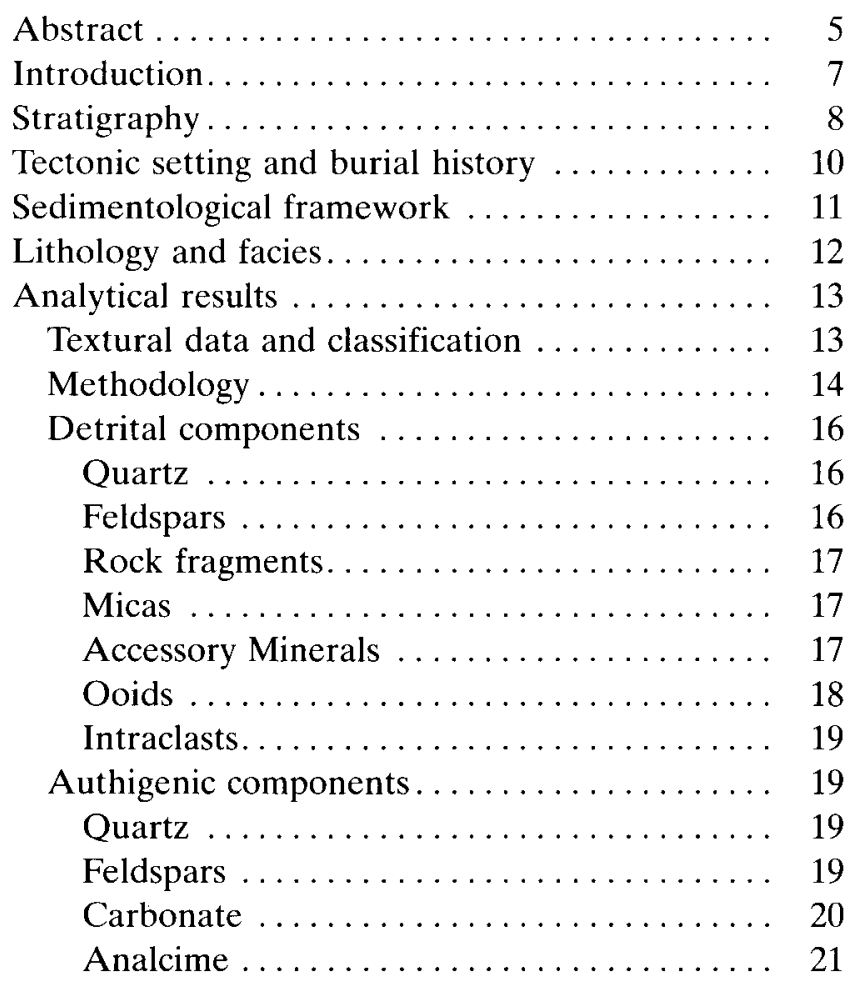

Anhydrite...................... 22

Barite ........................ 23

Clays......................... 23

Iron and titanium oxides............. 25

Halite ......................... 25

Porosity ........................ 25

Diagenesis ......................... 26

Diagenetic sequence ................ 26

Eogenetic regime ................... 27

Mesogenetic regime ................... 29

Patterns of diagenesis . . . . . . . . . . . . . . 29

Considerations ..................... 29

Diagenesis in relation to provenance ...... 30

Diagenesis in relation to lithofacies ...... 31

Diagenesis in relation to depth ......... 32

Diagenetic processes .................... 34

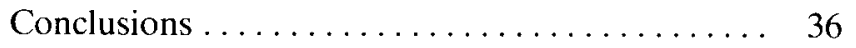

Summary ......................... 38

Acknowledgements .................... 38

References......................... 39

Plates ......................... 42 


\section{Abstract}

The Lower Triassic Bunter Sandstone Formation is a continental redbed sequence deposited under arid to semi-arid conditions in a low-energy, fluviatile-aeoliansabhka environment. The sediments display many diagenetic features in common with modern and ancient redbeds deposited under similar conditions, but local influences on the diagenetic assemblage by factors such as provenance, structural setting and depositional environment can be ascertained. With burial depths of only 1000-2000 meters, effects of compaction are limited, high intergranular porosities remain, and no clear depth-related patterns are noted.

The diagenetic assemblage consists of quartz and feldspar overgrowths, Fe-Ti oxides, carbonates (calcite and dolomite), analcime, authigenic clays, anhydrite and halite. The distribution of authigenic minerals is controlled by sedimentary facies, with greater amounts of poikilotopic anhydrite and halite in sandstones and more abundant dolomite and analcime in claystones and heterolithic sands. In addition, the replacement of ferromagnesian minerals by mixed-layer clays results in the greater abundance of these clays in sandstones relative to claystones.

A well-preserved eogenetic assemblage consisting of albite and quartz overgrowths, analcime, dolomite, calcite, gypsum and clays is indicative of highly evaporative conditions and may reflect higher sodium concentrations in the depositional brines associated with the more basinal, low-energy parts of the depositional environment. Such concentrated brines strongly influenced the diagenetic pathways. In contrast, anhydrite and halite are the product of mesogenetic reactions in association with late stage Zechstein brines which invaded the more permeable sands during halokinesis.

The strength and character of the depositional brine is an early control on subsequent diagenetic evolution. Within the specific geochemical regime of a given lithofacies, selective reactions occur which characterize particular microenvironments. These reactions impart an early eogenetic imprint upon later diagenetic events. 


\section{Introduction}

The following report summarizes one part of the Energy Research Project (EFP-83) entitled "The Diagenesis of Clastic Reservoir Rocks in the Danish Underground". The project, which was funded by the Danish Ministry of Energy, extended from August, 1983 March, 1986 and was a cooperative effort between the Geological Survey of Denmark (DGU), Dansk Olie \& Naturgas A/S (D.O.N.G.) and the Geological Institute of Aarhus University, Denmark. Project leadership was administrated by DGU; first by Stanley Fine through Sept. 1985 and thereafter by Palle Rubæk Andersen.

The purpose of the project was to document the detrital and diagenetic assemblages in four Triassic and Jurassic sandy formations and attempt to relate their diagenetic modifications to factors such as depth, provenance, lithofacies and tectonism. A database for the computer treatment of the many parametres used in a diagenesis study was also established.

The results of the project are presented in the following reports:
DGU publications series $A$ :

Part 1: Bunter Sandstone Formation (Triassic) by Stanley Fine.

Part 2: Gassum Formation (Triassic/Jurassic) by Henrik Friis.

Part 3: Haldager Formation (Jurassic) by Palle Rubæk Andersen.

\section{Internal Reports:}

Documentation for computer programmel and pointcounting procedure developed for the Diagenesis Project by Stanley Fine.

Skagerrak Project. Mineralogical composition and diagenetic processes in Skagerrak Formation sandstones by Viggo Jensen.

Preliminary investigation on the diagenesis of the interval 1983-2167 m b.RT. (Skagerrak Formation ?), Vinding-1 by Palle Rubæk Andersen.

Project summary report to the Ministry of Energy by Palle Rubæk Andersen and Stanley Fine. 


\section{Stratigraphy}

The Bunter Sandstone Formation forms the upper, arenaceous part of the Bacton Group, a sequence of Lower Triassic clastic redbeds previously designated as the Middle Bunter (Buntsandstein). The name Bunter Sandstone Formation was defined by Rhys (1974) for the southern North Sea Basin and his terminology was later introduced into Danish lithostratigraphic nomenclature by Bertelsen (1980).

The Bunter Sandstone Formation is found in the North German Basin in the Danish onshore region (fig 1). Although Bertelsen (1980) found that it coalesces with the Skagerrak Formation in the central part of the Danish-Norwegian Basin further to the north, later studies by Fine (1986), have since revised this transitional zone and designated the Ringkøbing-Fyn High as the boundary between these two formations.

The Bunter Sandstone Formation is underlain by the pelitic Bunter Shale Formation and overlain by the evaporitic Ørslev Formation (table 1). No formal subdivision of the Bunter Sandstone Formation has been undertaken, but separation into two distinct sandstone units, especially in the more southerly reaches of the Danish area, has proven feasible. Clemmensen (1986) relates these upper and lower sandstone sequences to German lithostratigraphic units in the central and southern part of the North German Basin.

\begin{tabular}{|c|c|c|c|c|}
\hline \multicolumn{4}{|c|}{ Germano-type Facies Province } & $\begin{array}{c}\text { Northern Marginal } \\
\text { Facies Province }\end{array}$ \\
\hline \multirow{3}{*}{ 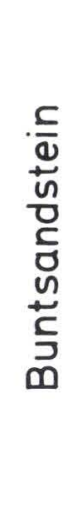 } & 范 & Lolland Group & Orslev Formation & \multirow[b]{2}{*}{ Skagerrak Formation } \\
\hline & & \multirow{2}{*}{ Bacton Group } & 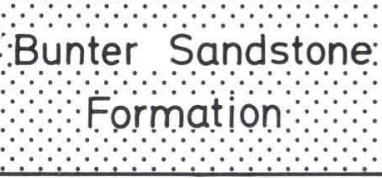 & \\
\hline & & & $\begin{array}{l}\text { Bunter Shale } \\
\text { Formation }\end{array}$ & Smith Bank Formation \\
\hline
\end{tabular}

Table 1. Lithostratigraphy of the Lower Triassic, Denmark. 


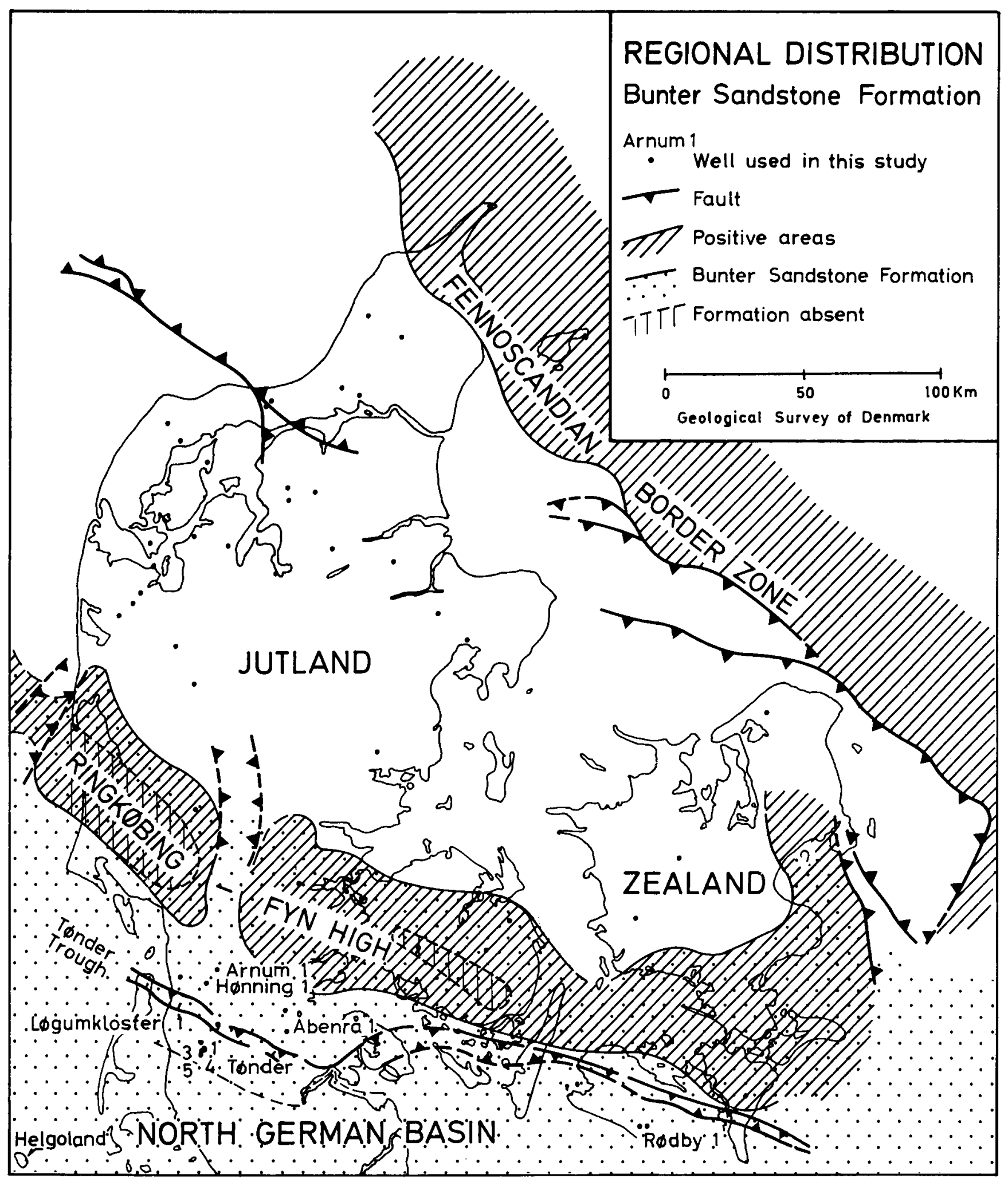

Fig. I. Regional distribution of the Bunter Sandstone Formation. The Tønder, Rødby and Helgoland localities lie upon salt structures. 


\section{Tectonic setting and burial history}

In the Danish area, the Bacton Group represents the first major regressive phase of the Triassic (Bertelsen 1980). Tectonic activity increased during deposition of the Bunter Sandstone Formation and clastic input into the basin increased. A probable Variscan event had originally divided the northern margin of the basin into a number of major and minor structural elements which played a significant role in the later depositional history of the region through a combination of differential subsidence and active faulting. Synsedimentary faulting was especially active during deposition of the Bunter Sandstone and indeed, an unconformity (Hardegsen tectonic event ?) may be present at the base of the Upper Bunter sand unit. These movements resulted in a step-like pattern of sedimentary piles which thicken from an average of $86 \mathrm{~m}$ in the most northerly structural block to $216 \mathrm{~m}$ in the most southerly one. Furthermore, movement of Zechstein salt during the early to middle Triassic led to the formation of the E-W trending Tønder trough (half-graben) (fig 1) and later halokenesis created the Tønder and Rødby salt pillows.
Little is known concerning the burial history of the region. The top of the Bunter Sandstone Formation is found today between approximately 1100-2000 metres, increasing in depth from north to south. However, post-burial inversion of the Triassic sequence is documented by both the absence of Jurassic sediments as well as a weak unconformity between the overlying Cretaceous beds and the Triassic. Although the amount of uplift is unknown, it probably did not exceed $500 \mathrm{~m}$ (Claus Andersen, pers. comm.). Halokinesis has locally disturbed this regional pattern along the southern margin of the Tønder Trough, but on a subordinate scale.

Modelled geothermal gradients of $25^{\circ}-35^{\circ} \mathrm{C} / \mathrm{km}$ (Michelsen et al. 1981) correlate well with bottom-hole values and suggest that current temperatures in the Bunter Sandstone Formation are around $60^{\circ}-70^{\circ} \mathrm{C}$ in the study area. However, even with a geothermal gradient of $40^{\circ} \mathrm{C} / \mathrm{km}$, and effective burial $500 \mathrm{~m}$ deeper than present depths, temperatures would probably not have exceeded $100^{\circ} \mathrm{C}$. 


\section{Sedimentological framework}

Recent sedimentological studies of the Danish Bunter Sandstone Formation have been undertaken by Bertelsen (1980) and Clemmensen (1986). Together with studies of the equivalent German middle Buntsandstein by Clemmensen (1979) and Mader (1982, 1983) among others, a picture emerges of alternating sabhka, aeolian and fluviatile deposition under relatively low energy conditions. To some extent, sedimentation was controlled by periodic variations in climate or tectonic activity which resulted in a discontinuous and variable supply of clastic material into the basin and led to the rapid fluctuation of depositional boundaries.

Paleogeographic reconstructions of German and British Lower Triassic sediments indicate an overall northerly transport direction from southern source regions (ie. Audley-Charles, 1970, Mader 1983). For the marginally located Danish Bunter Sandstone, however, heavy mineral studies (Larsen \& Friis 1975), wireline dipmeter surveys in some wells (Leth Nielsen, pers. comm.) and facies patterns (Clemmensen, 1986) indicate that fluvial progradation in this region was mainly from north to south and aeolian sediments may have been deposited by southerly as well as northeasterly paleowinds. On a local scale, changes in fluvial transport direction are considerably more variable, suggesting a significant degree of local control.

The Bunter Sandstone Formation generally consists of two sand units separated by a thick claystone interval. Each of these two major sandstone units is divided into a smaller number of sand beds which, on the basis of wireline $\log$ signatures, varies from about $1 \mathrm{~m}$ to nearly $25 \mathrm{~m}$ in thickness. Although the number of individual sand beds varies considerably within the Bunter Sandstone Formation as a whole, the sand/shale ratio is fairly consistent, generally with values between $20 \%$ and $35 \%$ net sand.

The lower Bunter sand is mainly a mixed aeolianfluvial-sabhka unit with sand beds 3-4 meters thick and very uniform total thicknesses of $33-36 \mathrm{~m}$. It is only found in wells south of the Tønder Trough and can be easily correlated because of its widespread lateral continuity.

The upper Bunter sand consists mostly of fluviatile, moderately-sorted sandstones which represent repeated flooding events by ephemeral streams. Numerous thin fining-upwards sequences are stacked upon one another, yielding total sand bed thicknesses up to nearly $25 \mathrm{~m}$. Since sabhka and lake mudstones up to several meters thick can interfinger with these sands, several distinct sand intervals can be recognized. No certain aeolian deposits are noted, but fluvial deposits may be partially reworked.

The upper Bunter sand is found throughout the investigated region. Unlike the lower Bunter sand however, it varies greatly in thickness (from 30-75 m), shows no regular distribution pattern, and has little lateral continuity. 


\section{Lithology and facies}

The Bunter Sandstone Formation consists of redbrown, yellow-brown and greenish grey sandstones, siltstones and claystones which locally can be more or less calcareous, dolomitic, anhydritic or micaceous. Samples are generally hard, but unconsolidated sandy layers also occur.

Sandstones are mostly very fine to fine-grained, although medium-grained sandstones, especially in the lower Bunter sand, are also found. No coarse-grained sands or gravels are present.

Siltstones are generally redder and more micaceous than the sandstones. Claystones are massive or laminated and have a variable silt content. They are redder and more micaceous than the coarser-grained sediments and may have scattered nodules of anhydrite (formerly gypsum) or cubes after halite. In general, the amount of total carbonate, anhydrite and halite is higher in the sandstones.

Clemmensen (1986) divided the Bunter Sandstone Formation into 14 sedimentary facies, but for the purposes of this study, these facies have been reduced to five major types. These are:

Facies 1: clay clast conglomerate.

Facies 2: massive or horizontally laminated claystone or siltstone.

Facies 3: heterolithic, clayey siltstone to fine-grained sandstone.

Facies 4: small scale cross-bedded, structureless, disturbed or horizontally laminated, mostly finegrained sandstone.

Facies 5: large scale cross-bedded, fine to mediumgrained sandstone.

It is emphasized that these facies have been used as lithofacies, representing increasing grain sizes from facies $2-5$. Facies 1 is poorly represented and not con- sidered further. In addition, since aeolian and fluviatile, rather than sabhka deposits, are the facies associations which have received the most interest, facies 4 \& 5 comprise about $75 \%$ of the investigated samples even though sandstones only make up around $25 \%$ of the entire Bunter Sandstone Formation. A typical sedimentological log is presented in fig. 2 .

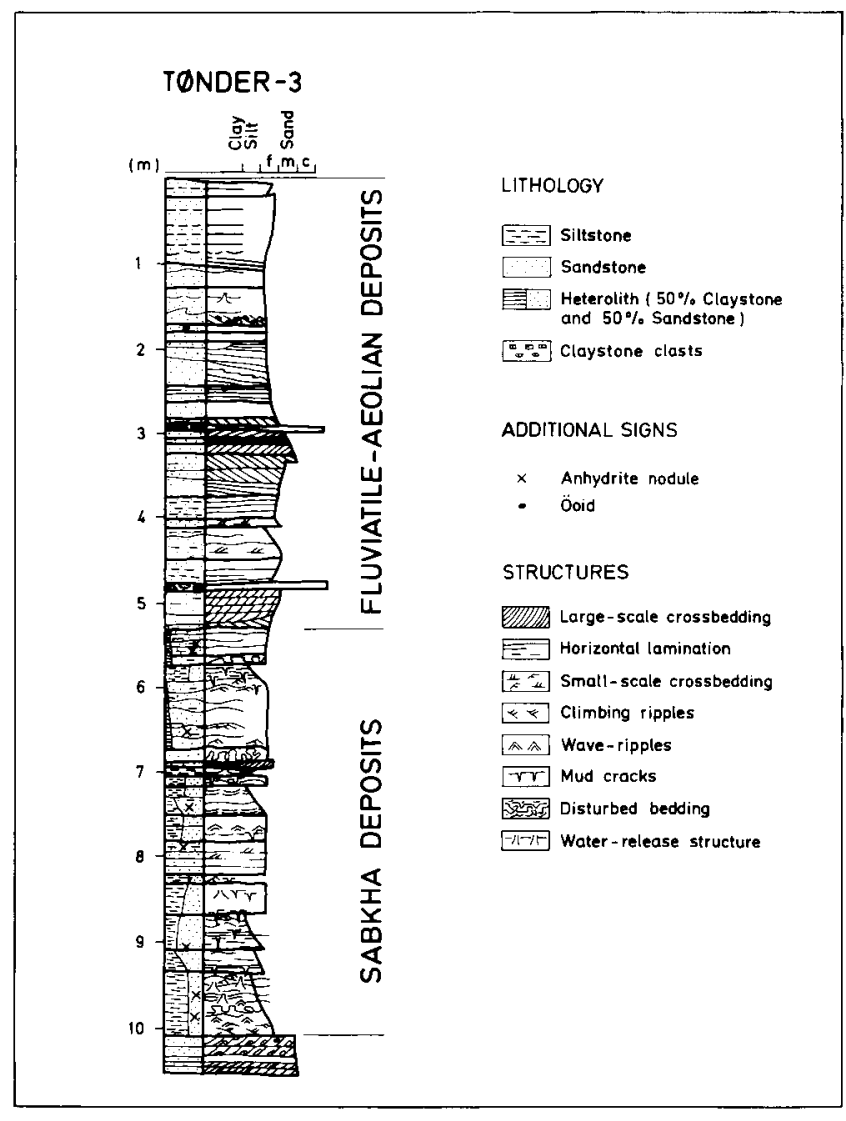

Fig. 2. Typical sedimentological log, Bunter Sandstone Formation. The sequence illustrated here is part of an 18 meter cored interval in the lower Bunter sand unit. 


\section{Analytical results}

\section{Textural data and classification}

Eight wells were incorporated into this study. Sampling is presented in figure 3 and clearly illustrates the large number of samples in the Tønder wells compared with the others. In order to study greater depth variations, some samples from Helgoland were also considered. Helgoland lies centrally in the North German Basin and is the closest outcrop of Buntsandstein to the Danish area (fig 1).

Fabric and textural data may be summarized as follows. Sorting varies from poor to good and may display considerable variation even within small intervals. Grains are generally subangular to subrounded, but the larger grains may be well-rounded. Textural maturity ranges from immature to mature, but is most commonly submature. The samples display few signs of significiant mechanical deformation and grain contacts are dominantly tangential to long.

Textural data can provide useful sedimentological information, but as pointed out by Wilson \& Pittman (1977) and many others, diagenetic processes can significantly alter these parameters and care must be taken in applying them. The data presented here is obviously subject to these considerations. Thus, while it is felt that grain size and sediment orientation reflect the depositional conditions fairly accurately, later events have modestly reduced the degree of sorting and textural maturity and increased the amount of mechanical deformation. Grain shape has also been changed, but more by marginal grain corrosion than by grain overgrowths.

Point-counted mineralogical data is given in table 2 . Samples consist of the following detrital fractions: $20-65 \%$ quartz, $5-20 \%$ feldspars and $2-12 \%$ rock fragments with minor and trace amounts of micas, opaques and heavy minerals and variable amounts of clay matrix. There are highly variable amounts of ooids and claystone intraclasts. Authigenic components include calcite, dolomite, anhydrite, barite, analcime, halite, quartz, feldspar, Fe-Ti oxides and clays. Visible thin section porosity ranges from $2-30 \%$ but averages $18 \%$.

According to Folk's classification (1968), the sandstones are subarkosic to arkosic. Figure 4 further illustrates that the samples from the Tønder wells, particularly those from Tønder-5, are somewhat more quartzrich than those from the Rødby-1, Arnum-1 and Hønning-1 wells. In addition, it is generally observed that the more coarse-grained sandstones (Facies 5) are less arkosic than the fine-grained sandstones (Facies 4).
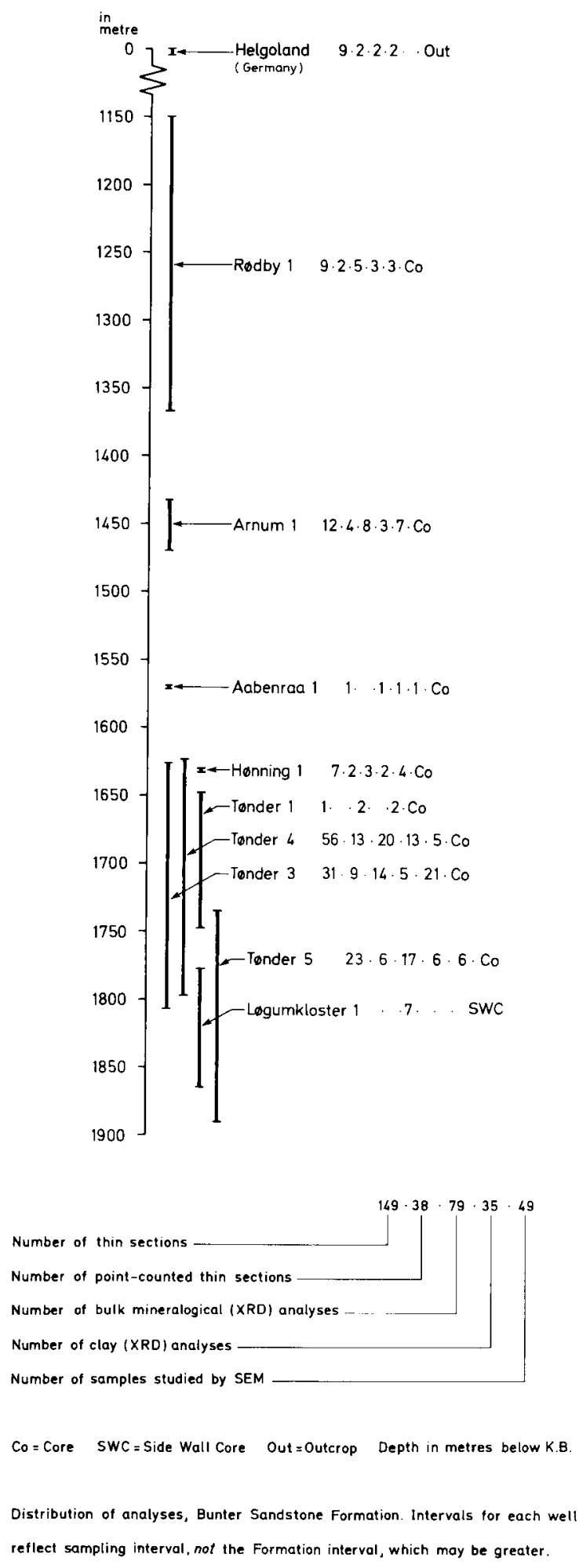

Fig. 3. Sampling profile, Bunter Sandstone Formation. The numbers in the legend are the sums for each type of analysis. 
This is probably a primary depositional feature and does not appear to be related to diagenetic modifications. A detailed petrographic description of all components follows below.

\section{Methodology}

Samples were analyzed by thin section, SEM, X-ray diffraction and electron microprobe. In addition, facies were assigned to samples based upon earlier sedimentological descriptions by workers at the Danish Geological Survey and Clemmensen (1986). All quantitative data were then treated by computer, using software developed especially for the project (Fine, 1985).

Thin sections were prepared on samples cut normal to bedding and were examined by classical optical methods. Point-counts were carried out on selected slides, aided by a combined Alizarin Red S Potassium ferricyanide stain for carbonates (Friedman 1971) and a sodium hexacobaltnitrate stain for K-feldspar (Ibid). All thin sections were impregnated with a blue-colored epoxy to aid porosity recognition. Between $350-500$ points were counted for each sample.

Scanning electron microscopy (SEM) was carried out on either a Cambridge MK 2 or a Cambridge S180 with EDS.

$\mathrm{X}$-ray diffraction was used to analyse samples for both their bulk mineralogical content and their $<2 \mu \mathrm{m}$ clay assemblages. It is recognized that the use of the $<$ $2 \mu \mathrm{m}$ fraction may have selectively removed kaolinite from the samples, but comparison with thin section and SEM data indicates that kaolinite was only found in very small amounts.

Bulk analyses have been quantified in an uncorrected manner such that individual mineralogical trends between samples may be discerned, but absolute values are meaningless and no scale is given on plots using bulk X-ray data. Clay minerals have been analyzed by the common methods (Carroll 1970). Clays have been quantified using a scale from 1-5 (see table 6 for explanation). Electron microprobe analyses were carried out on a JEOL 733 LINK energy-dispersive system with a ZAF/FLS-4 program. A $1 \mathrm{nA}$ current with focused beam was used. 
Table 2. Point-counted mineralogical data, Bunter Sandstone Formation. Values are in volume percent.

\begin{tabular}{|c|c|c|c|c|c|c|c|c|c|c|c|c|c|c|c|c|c|c|c|c|}
\hline $\begin{array}{l}\text { Sample } \\
\text { number }\end{array}$ & $\begin{array}{l}\text { Well } \\
\text { name }\end{array}$ & $\begin{array}{l}\text { Depth } \\
\text { (meter) }\end{array}$ & $\begin{array}{l}\text { Mono. } \\
\text { quartz }\end{array}$ & $\begin{array}{l}\text { Poly. } \\
\text { quartz }\end{array}$ & $\begin{array}{c}\text { Plagio- } \\
\text { clase }\end{array}$ & $\begin{array}{l}\text { K-Feld- } \\
\text { spar }\end{array}$ & $\begin{array}{l}\text { Sediment- } \\
\text { ary rock } \\
\text { fragm. }\end{array}$ & $\begin{array}{l}\text { Crystal- } \\
\text { line rock } \\
\text { fragm. }\end{array}$ & $\begin{array}{l}\text { Total } \\
\text { mica }\end{array}$ & $\begin{array}{c}\text { Heavy } \\
\text { mineral and } \\
\text { opaques }\end{array}$ & Ooids & $\begin{array}{l}\text { Intra- } \\
\text { clasts }\end{array}$ & Calcite & $\begin{array}{l}\text { Dolo- } \\
\text { mite }\end{array}$ & $\begin{array}{c}\text { Total } \\
\text { carbonate }\end{array}$ & $\begin{array}{l}\text { Anhyd- } \\
\text { rite }\end{array}$ & analcime & $\begin{array}{l}\text { Total } \\
\text { clays }\end{array}$ & $\begin{array}{c}\text { Total } \\
\text { porosity }\end{array}$ & facies \\
\hline 1948 & Helgoland & 0.00 & 38.1 & 12.0 & 1.6 & 10.7 & 0.3 & 6.3 & & 0.3 & 3.4 & & 2.9 & & 2.9 & & 1.0 & & 22.2 & 5 \\
\hline 1949 & Helgoland & 0.00 & 45.3 & 9.0 & 1.0 & 9.0 & & 5.2 & & & 0.3 & & 8.0 & & 8.0 & & & 3.8 & 19.0 & 5 \\
\hline 1641 & Rødby-1 & 1151.72 & 40.2 & 6.6 & 2.2 & 10.7 & 0.4 & 8.1 & & 0.4 & & & & & & & 0.4 & & 15.5 & 4 \\
\hline 1261 & Rødby-1 & 1367.78 & 44.2 & 5.2 & 4.5 & 8.3 & 0.2 & 5.5 & 0.2 & & & 1.4 & 7.8 & & 7.8 & 0.2 & 1.2 & 2.4 & 18.8 & 4 \\
\hline 1264 & Arnum-1 & 1440.48 & 21.6 & 0.8 & 3.5 & 9.1 & 0.2 & 2.5 & 6.0 & 0.6 & & 20.0 & 3.1 & 2.9 & 6.0 & & 1.4 & 16.7 & 11.7 & 4 \\
\hline 1265 & Arnum-1 & 1440.48 & 23.2 & 2.3 & 4.2 & 11.4 & 0.2 & 2.3 & 4.2 & 1.6 & & 12.5 & 2.3 & 4.6 & 6.9 & & & 16.9 & 14.2 & 4 \\
\hline 1269 & Arnum-1 & 1442.98 & 33.3 & 1.9 & 4.7 & 10.8 & & 6.1 & 1.7 & 1.4 & & 3.8 & 7.3 & & 7.3 & & 0.2 & 6.8 & 21.9 & 4 \\
\hline 1268 & Arnum-1 & 1444.18 & 26.9 & 3.1 & 6.7 & 10.2 & & 4.1 & 6.1 & 0.2 & & 6.5 & 4.5 & & 4.5 & & 1.6 & 10.2 & 19.8 & 4 \\
\hline 1273 & Hønning-1 & 1632.95 & 34.7 & 3.0 & 5.7 & 13.7 & & 3.4 & 0.7 & 0.2 & & 3.0 & & & 8.0 & & 0.5 & 6.2 & 21.0 & 4 \\
\hline 1274 & Hønning-1 & 1633.60 & 35.9 & 4.9 & 5.6 & 12.2 & 0.4 & 2.7 & 1.4 & 1.2 & 0.4 & 3.5 & & & 7.0 & 0.2 & 0.8 & 8.2 & 15.5 & 4 \\
\hline 1153 & Tønder-3 & 1651.03 & 26.4 & 2.1 & 6.8 & 10.2 & 1.0 & 6.4 & 3.4 & 1.1 & & 5.3 & $\mathrm{P}$ & $\mathrm{P}$ & & 6.0 & 0.9 & & 18.4 & 4 \\
\hline 579 & Tønder-3 & 1657.00 & 30.2 & 6.5 & 5.3 & 9.3 & 2.8 & 5.3 & & 0.9 & 0.3 & 4.0 & & & 7.4 & 9.0 & 0.3 & & 15.6 & 4 \\
\hline 1155 & Tønder-3 & 1671.30 & 43.4 & 7.0 & 2.2 & 6.2 & 0.6 & 4.6 & $\mathrm{P}$ & 0.4 & 0.8 & 1.8 & 3.9 & & 3.9 & 0.6 & 0.2 & 0.8 & 25.5 & 5 \\
\hline 580 & Tønder-3 & 1671.30 & 43.0 & 7.9 & 1.1 & 7.9 & 0.4 & 2.6 & & 0.6 & 0.7 & 1.3 & & & 3.9 & 0.4 & 0.4 & 2.4 & 27.3 & 5 \\
\hline 1163 & Tønder-3 & 1675.26 & 36.9 & 3.9 & 3.0 & 8.4 & 0.2 & 4.1 & 0.6 & 0.6 & & & 7.3 & 0.4 & 7.7 & & 1.1 & 19.0 & 14.4 & 4 \\
\hline 1156 & Tønder-3 & 1677.24 & 36.1 & 7.4 & 4.1 & 8.0 & 1.1 & 6.3 & & 3.2 & 0.4 & 0.9 & & & 3.5 & 0.4 & 0.6 & 4.8 & 17.1 & 5 \\
\hline 1157 & Tønder-3 & 1795.00 & 57.9 & 5.2 & 0.2 & 5.8 & 0.4 & 3.0 & 0.6 & 1.7 & & 2.4 & & & & & & & 22.3 & 5 \\
\hline 1159 & Tønder-3 & 1795.00 & 28.3 & 4.5 & 3.6 & 14.5 & & 8.3 & & & 8.3 & 0.2 & 4.8 & 5.7 & 10.5 & & 0.5 & 3.8 & 17.2 & 5 \\
\hline 1158 & Tønder-3 & 1806.05 & 35.8 & 5.5 & 2.5 & 9.4 & 0.4 & 3.6 & 0.2 & & 0.4 & 2.3 & 0.6 & 7.1 & 7.7 & 6.7 & 0.8 & 5.5 & 19.3 & 5 \\
\hline 1288 & Tønder-4 & 1642.20 & 29.0 & 3.1 & 4.1 & 8.4 & 0.4 & 2.3 & 1.6 & 0.6 & 0.2 & 5.1 & & & 7.2 & 21.8 & 0.6 & 10.5 & 5.1 & 4 \\
\hline 1276 & Tønder-4 & 1658.15 & 25.9 & 3.5 & 6.4 & 9.1 & 0.3 & 3.7 & 1.6 & 1.1 & & 4.3 & 4.8 & & 4.8 & 2.1 & 2.4 & 15.2 & 19.5 & 5 \\
\hline 1279 & Tønder-4 & 1664.30 & 30.5 & 4.5 & 8.4 & 7.5 & & 5.2 & 1.8 & 1.1 & 0.2 & 2.3 & & & 4.5 & 1.4 & 1.4 & 5.9 & 25.3 & 4 \\
\hline 1280 & Tønder-4 & 1666.05 & 31.7 & 3.7 & 7.6 & 5.7 & 0.2 & 5.0 & 2.1 & 2.1 & & 3.4 & & & 7.6 & & 1.6 & 5.5 & 23.9 & 4 \\
\hline 1281 & Tønder-4 & 1667.80 & 32.1 & 4.9 & 9.0 & 12.1 & 1.1 & 10.7 & & 0.3 & $\mathrm{P}$ & 1.3 & & & 4.8 & & 1.4 & 3.8 & 18.0 & 5 \\
\hline 1282 & Tønder-4 & 1669.50 & 34.1 & 7.7 & 6.2 & 6.8 & & 5.7 & & 0.4 & 0.2 & 5.3 & & & 6.8 & 0.7 & 0.4 & 2.4 & 23.3 & 5 \\
\hline 1283 & Tønder-4 & 1671.00 & 26.2 & 5.6 & 4.9 & 5.6 & & 4.3 & 2.0 & 1.6 & 0.2 & 0.7 & & & 6.7 & 3.8 & 1.8 & 20.6 & 15.9 & 4 \\
\hline 1297 & Tønder-4 & 1679.50 & 37.9 & 7.8 & 6.2 & 5.8 & 0.2 & 6.2 & & 1.0 & 1.0 & 1.4 & & & 4.8 & 0.8 & 1.2 & 3.8 & 22.0 & 5 \\
\hline 1298 & Tønder-4 & 1681.25 & 19.7 & 3.7 & 2.5 & 3.7 & & 1.9 & & 0.2 & 0.2 & 48.1 & & & 2.1 & 7.9 & 0.5 & 4.4 & 2.1 & 1 \\
\hline 1305 & Tønder-4 & 1684.30 & 43.5 & 4.8 & 3.5 & 7.0 & 0.2 & 3.1 & & 0.8 & 0.4 & 2.5 & & & 4.1 & 8.8 & 0.6 & 0.6 & 20.3 & 5 \\
\hline 1302 & Tønder-4 & 1689.15 & 49.0 & 7.0 & 5.0 & 6.0 & 0.2 & 3.0 & 0.2 & 0.5 & 1.0 & 0.2 & & & 3.0 & 2.0 & 1.0 & 0.4 & 12.5 & 5 \\
\hline 1635 & Tønder-4 & 1776.50 & 32.2 & 7.8 & 7.0 & 10.1 & 0.2 & 7.8 & & 0.8 & 1.1 & & 8.1 & 1.4 & 9.5 & 2.0 & 2.5 & 0.8 & 17.6 & 4 \\
\hline 1637 & Tønder-4 & 1795.21 & 29.0 & 5.1 & 9.9 & 9.5 & 0.3 & 10.1 & & 0.3 & 1.4 & 0.7 & 8.4 & 0.3 & 8.7 & & 2.4 & 5.4 & 16.6 & 4 \\
\hline 1309 & Tønder-5 & 1738.47 & 47.9 & 4.3 & 4.7 & 4.7 & 0.2 & 4.3 & & 1.4 & 0.2 & 1.0 & 5.7 & & 5.7 & & 0.6 & 6.3 & 18.6 & 4 \\
\hline 1310 & Tønder-5 & 1739.59 & 44.7 & 7.5 & 6.3 & 3.5 & 1.0 & 2.3 & 0.3 & & & 0.5 & & & & 7.3 & 0.5 & 4.0 & 22.1 & 5 \\
\hline 1311 & Tønder-5 & 1739.91 & 46.5 & 7.1 & 3.5 & 3.3 & 0.7 & 4.7 & & & & & & & 0.2 & 16.5 & & & 17.0 & 5 \\
\hline 962 & Tønder-5 & 1857.35 & 41.6 & 7.1 & 4.5 & 5.5 & 0.4 & 3.9 & & & & & 1.8 & 2.0 & 3.8 & 15.6 & & 6.1 & 11.0 & 4 \\
\hline 963 & Tønder-5 & 1860.45 & 42.0 & 5.3 & 4.2 & 7.8 & 1.1 & 1.7 & & & 2.5 & 0.3 & & & 2.0 & 0.3 & & 2.5 & 30.3 & 5 \\
\hline 967 & Tønder-5 & 1871.55 & 29.5 & 10.5 & 0.7 & 4.5 & 0.4 & 2.2 & & 0.2 & 26.7 & 0.9 & 6.4 & 3.2 & 9.6 & 0.7 & 0.6 & 3.0 & 10.5 & 5 \\
\hline 970 & Tønder-5 & 1879.70 & 32.2 & 9.8 & 4.4 & 5.4 & & 3.2 & $\mathrm{P}$ & 0.9 & 2.5 & & & & 10.4 & 0.3 & 4.7 & & 17.0 & 4 \\
\hline $\begin{array}{l}\text { Average: } \\
\text { Interval: }\end{array}$ & & & $\begin{array}{c}35.6 \\
19.7: 57.9\end{array}$ & $\begin{array}{c}5.5 \\
0.8: 12.0\end{array}$ & $\begin{array}{c}4.6 \\
0.2: 9.8\end{array}$ & $\begin{array}{c}8.2 \\
3.3: 14.5\end{array}$ & $\begin{array}{c}0.5 \\
0.2: 2.8\end{array}$ & $\begin{array}{c}4.7 \\
1.7: 10.7\end{array}$ & $\begin{array}{c}1.7 \\
\text { P:6.1 }\end{array}$ & $\begin{array}{c}0.9 \\
0.2: 3.2\end{array}$ & $\begin{array}{c}2.2 \\
\mathbf{P}: 26.7\end{array}$ & $\begin{array}{c}4.7 \\
0.2: 48.1\end{array}$ & $\begin{array}{c}4.9 \\
P: 8.4\end{array}$ & $\begin{array}{c}2.8 \\
P: 7.1\end{array}$ & $\begin{array}{c}6.0 \\
0.2: 10.5\end{array}$ & $\begin{array}{c}4.8 \\
0.221 .8\end{array}$ & $\begin{array}{c}1.1 \\
02.47\end{array}$ & $\begin{array}{l}6.5 \\
4 \cdot 206\end{array}$ & 18.1 & \\
\hline
\end{tabular}




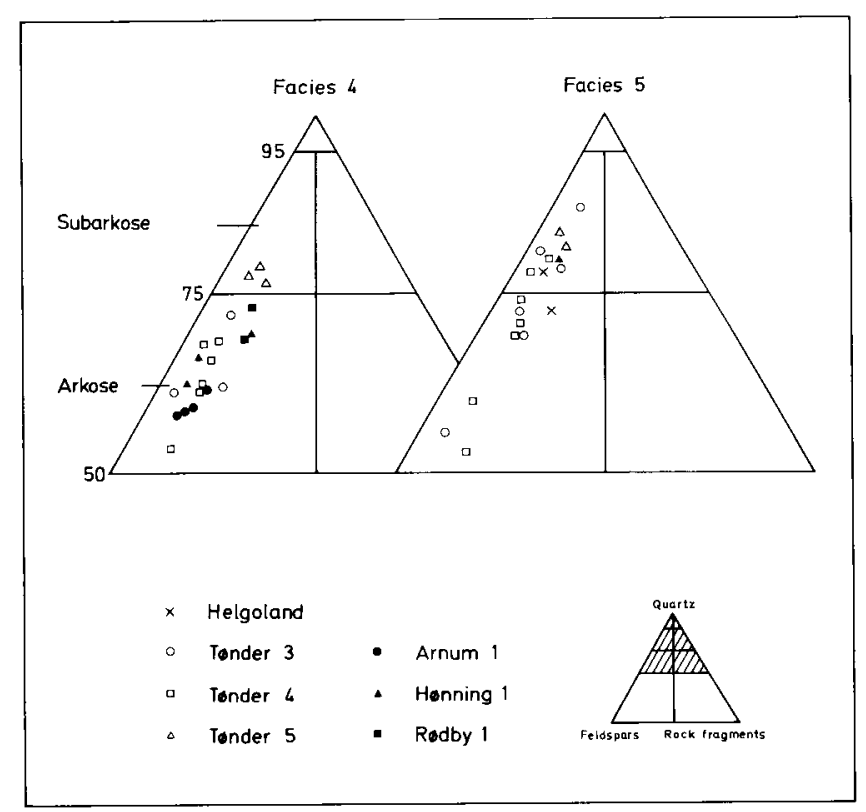

Fig. 4. Rock classification, after Folk (1968).

\section{Detrital components}

\section{Quartz}

Both monocrystalline and polycrystalline types are present. Monocrystalline grains range in amounts from $19.7-57.9 \%$ with approximately equal proportions of straight and slightly undulose varieties. Polycrystalline grains, identified as having 3 or more composite grains, are always subordinate in number and although some quartz grains have characteristics common to a metamorphic source, no clear genetic association emerges. Finally, rare and scattered second-cycle quartz grains have been observed. These tend to be larger than the average grain size and may be identified by rounded overgrowths and/or an anomalous clay lining texture (plate 1A).

The degree of alteration increases from unstrained to strained to polycrystalline types (table 3 ). In detail however, the degree of quartz alteration varies greatly from grain to grain. Clays, carbonates and anhydrite may all corrode and replace quartz and although no clear pattern is seen, it nevertheless appears that whereas clay is the dominant element attacking polycrystalline quartz, no preferential alteration by any authigenic component is noted for the fresher monocrystalline grains. Alteration of polycrystalline grains commonly occurs along crystal boundaries, with the result that these grains undergo pronounced intragranular dissolution leading to disaggregation of the polycrystalline fragment and subsequent creation of a secondary silt-sized fraction. Although intragranular dissolution may occur in up to $25 \%$ of the polycrystalline quartz grains, it is noted in less than $3 \%$ of the monocrystalline grains, perhaps due here to the preferential removal of inclusions. Marginal corrosion, on the other hand, is noted for both quartz types.

Grains are commonly coated by an iron-oxide stained clay and original surface features are difficult to detect. Frosted grains and rare mechanically induced $\mathrm{V}$-shaped indentations have rarely been observed by SEM however (plate 2A).

\section{Feldspars}

Both plagioclase and alkali feldspar is present. K-feldspar $(8-14.5 \%)$ is generally more abundant than plagioclase (5-9.8\%) although they may occur in approximately equal amounts. The K-feldspars consist of nearly equal amounts of microcline and untwinned $\mathrm{K}$ feldspar (orthoclase) with subordinate perthite. Microcline may be more common than untwinned K-feldspar in the Upper Bunter Sandstone. Microprobe data indicates that the plagioclase feldspars compositionally range from albite to andesine.

The freshness of the feldspar varies considerably. Feldspar alteration includes vacuolization, sericitization, replacement and leaching. In general, plagioclase is only slightly more "dirty" in appearance than K-

\begin{tabular}{|c|c|c|c|c|c|}
\hline & 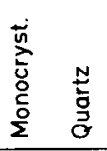 & 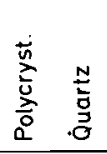 & 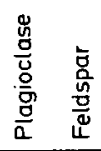 & 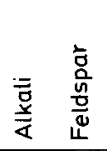 & 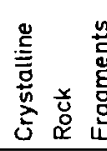 \\
\hline \multicolumn{6}{|l|}{$\begin{array}{l}\text { Degree of } \\
\text { Alteration: }\end{array}$} \\
\hline Fresh & $\begin{array}{c}74-91 \\
85\end{array}$ & $\begin{array}{c}32-75 \\
48\end{array}$ & $\begin{array}{c}7-29 \\
16\end{array}$ & $\begin{array}{c}18-69 \\
37\end{array}$ & $\begin{array}{l}6-24 \\
12\end{array}$ \\
\hline Moderately & $9-25$ & $25-50$ & $31-71$ & $25-60$ & $39-59$ \\
\hline Altered & 14 & 38 & 51 & 48 & 47 \\
\hline Very & $1-2$ & $6-27$ & $14-48$ & $6-32$ & $32-53$ \\
\hline $\begin{array}{l}\quad \text { Altered } \\
\text { Replacement } \\
\text { By: }\end{array}$ & 1 & 16 & 33 & 17 & 44 \\
\hline Carbonate & $\begin{array}{c}2-18 \\
6\end{array}$ & $\begin{array}{c}1-19 \\
12\end{array}$ & $\begin{array}{c}6-40 \\
16\end{array}$ & $\begin{array}{c}11-31 \\
16\end{array}$ & $\begin{array}{c}3-20 \\
15\end{array}$ \\
\hline Anhydrite & $\begin{array}{c}1-7 \\
4\end{array}$ & $\begin{array}{l}5 \\
5\end{array}$ & $\begin{array}{c}11-13 \\
12\end{array}$ & $\begin{array}{c}3-20 \\
9\end{array}$ & $\begin{array}{c}7-19 \\
15\end{array}$ \\
\hline Clays & $\begin{array}{c}2-26 \\
7\end{array}$ & $\begin{array}{c}5-75 \\
34\end{array}$ & $\begin{array}{c}20-68 \\
48\end{array}$ & $\begin{array}{c}7-68 \\
38\end{array}$ & $\begin{array}{c}25-69 \\
58\end{array}$ \\
\hline Intragranular & & & & & \\
\hline $\begin{array}{l}\text { Dissolution: } \\
\text { Overgrowths }\end{array}$ & $\begin{array}{c}1-3 \\
2\end{array}$ & $\begin{array}{c}5-24 \\
15\end{array}$ & $\begin{array}{c}7-43 \\
23\end{array}$ & $\begin{array}{c}6-25 \\
14\end{array}$ & $\begin{array}{c}28-69 \\
47\end{array}$ \\
\hline Observed: & $\begin{array}{c}1-19 \\
10\end{array}$ & $\begin{array}{c}38-59 \\
5\end{array}$ & $\begin{array}{c}4-37 \\
18\end{array}$ & $\begin{array}{c}8-37 \\
18\end{array}$ & - \\
\hline
\end{tabular}

Table 3. Percent alteration of detrital grains, based on point-counts. The terms fresh, moderately altered and very altered are subjective. 
feldspar, but plagioclase has undergone a considerably greater degree of dissolution than the potassium feldspar. Microprobe analyses of partially leached plagioclase grains show a wide range in composition. In two andesines of similar composition for example, one may be very fresh while the other is strongly leached. As discussed by Berner and Holdren (1977), such variability is probably controlled by the structural state of the feldspar.

Replacement occurs either irregularly and/or preferentially along cleavage traces. Both thin section and SEM microphotographs clearly illustrate this structural control (plates 1B, 2B, 2C). Dramatic grain dissolution is also observed, particularly for plagioclase and especially within grain interiors. Despite this intensive leaching, the skeletal grains relicts generally preserve an identifiable grain morphology (plate 1C).

The feldspars are most commonly altered to clay. Carbonate and anhydrite replacement may play a locally significant role. It should be noted that whereas the number of feldspar and other detrital grains being replaced by carbonate or anhydrite correlates reasonably well with the modal distribution of these cements in thin section, the number of detrital grains being replaced by clay is proportionally much greater than the total amount of clay observed in thin section (fig. 5). In other words, both clayey and relatively clay-free sands have approximately equal amounts of clay-altered feldspar, which suggests that some feldspar alteration may be pre-depositional.

\section{Rock fragments}

Crystalline rock fragments range from 1.7 to $11.8 \%$ of the terrigeneous fraction. Metamorphic and igneous rock fragments are the most common and include mostly granites and gneisses with subordinate phyllites and schists. Within an approximate 15 meter interval in the Upper Bunter Sandstone in Tønder-3 and Tønder-4, granitic fragments with a myrmekitic texture are a common component of the crystalline rock fragments and may be a useful means of correlation between these two wells. Volcanic rock fragments were not observed.

Detrital sedimentary rock fragments never exceed $3 \%$. They include chert $(<1 \%)$ as well as some greenish, possible siltstone fragments. Red claystone clasts are a common component (fig. 2) but sedimentological criteria suggests that they are intraformational, perhaps rip-up clasts from overbank deposits (Clemmensen, 1986). As such, they are not included together with the above-mentioned terrigeneous grains and are similarly not incorporated in a rock classification triangle of Folk (1968) (fig. 4).

Of all the detrital components, rock fragments are most affected by alteration. Less than $25 \%$ of the crys- talline fragments may be classified as fresh but between $32-53 \%$ are classified as very altered (see table 3 ). In fact, the percentage of altered rock fragments is probably underestimated since extensive alteration makes recognition of such grains problematic. As was also the case for polycrystalline quartz and feldspar grains, clay replacement is the dominant type of alteration and feldspars are preferentially altered relative to quartz within a given rock fragment. When present, replacement by anhydrite or carbonate is less mineralogically selective and seems to attack the grain as a whole.

Dissolution of rock fragments is a common feature, observed in $30 \%$ to nearly $70 \%$ of the grains. The feldspars are preferentially leached, leading to the formation of secondary porosity and the eventual disaggregation of these composite fragments. The pervasive leaching of sedimentary rock fragments or intraclasts indicates that cherts and clays have also been subject to removal. In most cases, accompanying marginal corrosion has resulted in pitted and etched surfaces and irregular grain shapes.

\section{Micas}

Micas generally range from $<1-3 \%$ in the investigated sandstones although up to $6 \%$ was encountered in $\mathrm{Ar}$ num-1. Micas clearly increase in the more poorlysorted silt- and claystones and visual estimates indicate that between $5-10 \%$ micas are present here. There is a tendency for the fluviatile Upper Bunter Sandstones to be more enriched in micas than the more aeolian Lower Bunter Sandstones.

Biotite is the most common mica, followed by muscovite and rare chlorite. As described by Turner (1980, p. 286), biotites are commonly oxidized, and develop hematite along cleavage traces, but this type of alteration varies considerably. In extreme cases, the biotite has been entirely replaced by iron oxides. Clay replacement has also been observed, but the type of clay could not be determined. SEM microphotographs of biotites reveal surfaces which are pitted and examples of carbonate replacement have been noted.

The micas in the claystones are generally undeformed and although similarly undeformed grains are seen in the sandstones, micas are commonly bent or even splintered here. Plate 1D illustrates a muscovite grain which has been deformed by an unknown grain which must have been leached at a later point.

\section{Accessory minerals}

The accessory minerals are divided into non-opaque and opaque groups. Less than $1 \%$ non-opaques and up to $3 \%$ opaques may be scattered throughout a sample. Thin, well-sorted stringers have been noted in a few samples of the Upper Bunter Sandstone. 


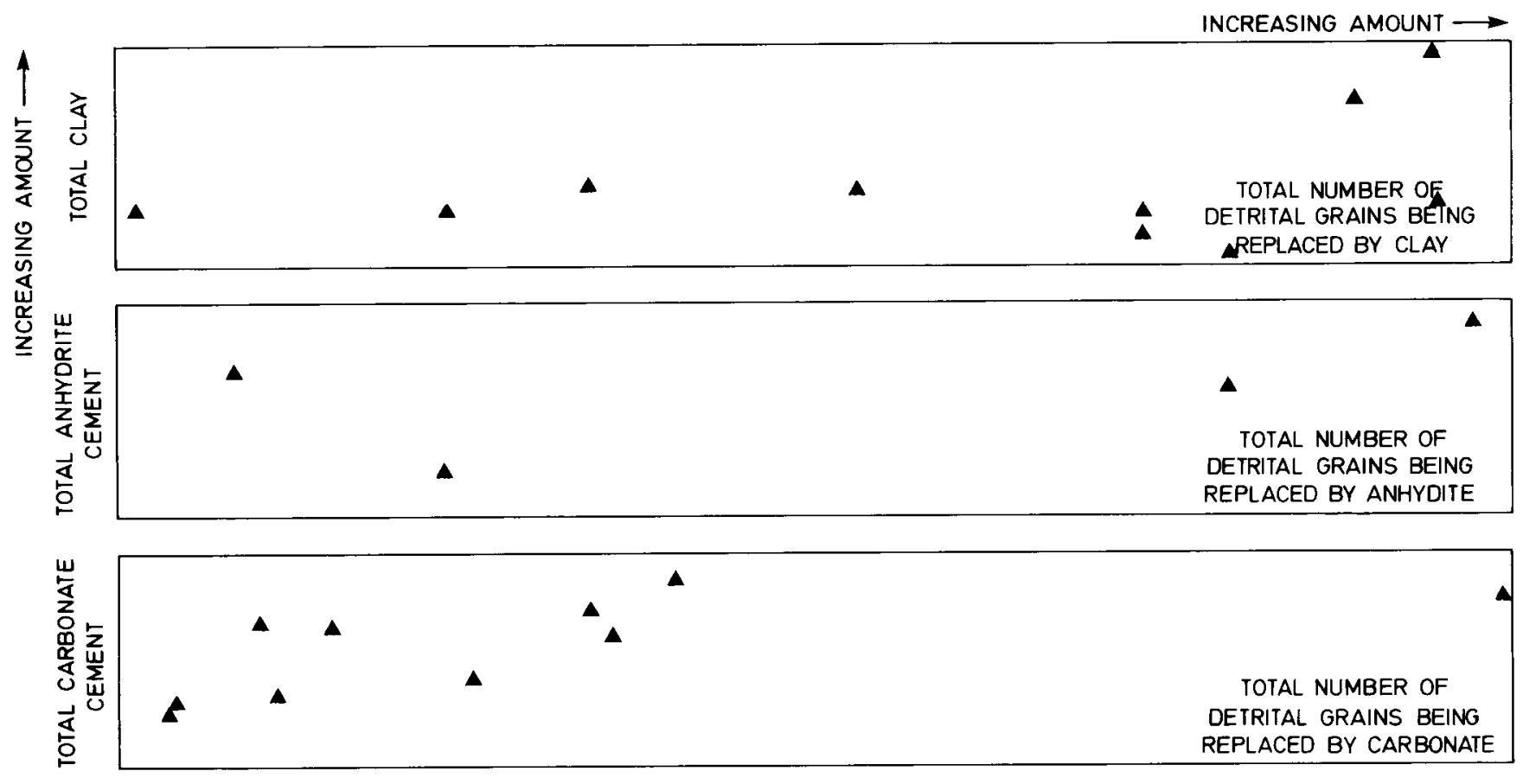

Fig. 5. Degree of alteration of detrital grains vs. total abundance of the replacing phase. Quantification from point-counts.

The non-opaque accessories consist dominantly of garnet with subordinate zircon and much rarer epidote, rutile, apatite, tourmaline and sphene. The garnets and zircons are well-rounded and appear to be relatively fresh but when studied as heavy mineral separates, corrosion of the garnets is apparently more pronounced (Henrik Friis, pers. comm.)

No attempt was made to quantitatively distinguish between primary and secondary opaque minerals. The opaque minerals are dominantly hematite with lesser amounts of magnetite and anatase. Microcrystalline hematite is especially associated with clay and causes the strong red coloring in the sediments. Iron-bearing phases such as biotites and former ferromagnesian minerals often have a particularly strong stain. Walker (1967), Walker and Honea (1969), Ixer et. al. (1979), Turner (1980) and Morad (1983) have described the processes involved in the coloring of redbeds.

\section{Ooids}

Ooids are found in amounts ranging from $<1 \%$ to around $30 \%$ (table 2 ). In detail however, ooids are either concentrated in thin horizons in aeolian beds from the Lower Bunter Sandstone or found as single, scattered grains in both Lower and Upper Bunter units.

Ooids range in size from $0.1-0.4 \mathrm{~mm}$ and closely parallel the sedimentary sorting within a given thin section. They are largest and best preserved in the ooidrich laminae. Oolites (ooid-rock fragments) are sometimes observed as well. The source of the ooids is unknown. Clemmensen (1986) suggests that they could be contemporaneous, wind-blow, marginal lake deposits but ooids are also known from both the underlying Bunter Shale Formation (Bertelsen 1980) as well as the Permian (Clark \& Tallbacka 1980).

Both tangential and radial substructures, as described by Simone (1981), are seen in the ooids. These two types occur in approximately equal amounts, show several generations of growth interrupted by ferricstained concentric rings and may have variably thick drusy, pore-filling calcite crystals growing radially from their margins (plates 1E, 2D). A calcite-replaced quartz or feldspar nucleus is sometimes noted.

When compared with the ooid-rich laminae, the smaller, scattered ooids are more irregular in shape and their internal structure is more indistinct. In addition, pore-filling, drusy calcite crystals tend to be poorly developed on these ooids.

Ooids are often affected by intragranular dissolution. Even in the ooid-rich horizons, where the ooids appear least altered, around $25 \%$ show signs of leaching. Furthermore, internal dissolution is sometimes noted despite the presence of thick authigenic growth outwards from the margins of the same grain (plate $1 \mathrm{~F}$ ). This authigenic growth has rarely been noted growing inwards into the leached ooid interior. Ooids have also been affected by pre-depositional fracturing as well as postdepositional compaction and pressure solution. The latter process results in deformation of these relatively soft fragments by squeezing between, and penetration by, harder detrital grains such as quartz and feldspar (plate 2E), and sutured contacts may result. There is often an unusually thick iron oxide lining along these contacts. Staining indicated that the ooids were iron 
free calcites and microprobe analyses of ooid interiors and drusy authigenic margins proved that they both consist of nearly pure $\mathrm{CaCO}_{3}$. No compositional zoning was evident.

\section{Intraclasts}

Due to the combined diagenetic processes of deformation, replacement and dissolution, the primary character of sedimentary intraclasts has often been masked. In addition, similar diagenetic processes affecting labile grains such as feldspars, micas and crystalline rock fragments can lead to misidentification of these detritals as intraclasts.

Claystone and siltstone intraclasts have been recognized. They were identified by criteria such as texture and grain size, color, type of alteration, resemblance to matrix and the adjacent clay layers and resemblance to each other. The intraclasts range from $<1 \%$ to nearly $48 \%$ in thin section, may be up to $0.8 \mathrm{~cm}$ in length and are especially abundant in the Upper Bunter Sandstone. They are generally red-brown in color and may display lamination. In certain intervals, the clasts may contain either gypsum (now anhydrite) prisms or dolomite rhombs (plates $1 \mathrm{G}, 2 \mathrm{~F}$ ). The presence of reddish clots of clay within some colourless or yellowish micritic fragments suggests that they may be totally replaced clay- or siltstone clasts.

Mechanical compaction of the relatively soft clasts has often resulted in the development of a pseudomatrix and it may be noteworthy that the squeezed clasts are commonly the best preserved. Intragranular dissolution has played an important role; at least $25 \%$ of the intraclasts are leached and marginal corrosion is observed throughout. The siltstone clasts tend to be more leached than the more strongly reddish-stained claystone clasts. Leaching of the micritic clasts varies greatly. Replacement and secondary pore-filling of leached clasts by carbonate, anhydrite, clays? and analcime are frequently noted.

\section{Authigenic components}

The following authigenic minerals have been found: quartz, feldspar, carbonate, analcime, anhydrite, barite, halite, iron and titanium oxides and various clays. These minerals occur as products of several diagenetic processes including replacement and precipitation, they may occur in one, two or more generations and they often show complex relationships with one another. Yet, despite the many cements and the $1-2 \mathrm{~km}$ burial depths, some of the sandstones are unconsolidated and others display no apparent form of bonding other than thin hematite-stained, tangentially oriented clay pellicles around the detrital grains.
The minerals are discussed individually in detail below.

\section{Quartz}

Optically continuous quartz overgrowths are found in nearly all samples. They occur on up to $19 \%$ of the quartz grains in any given thin section (table 2), but they are very small and volumetrically contribute less than $1 \%$ to the rock. The overgrowths occur most frequently on monocrystalline grains but are occasionally noted on polycrystalline grains as well. Although overgrowths are easily noted by SEM, petrographic recognition is usually based upon the presence of a thin dust ring on detrital grain surfaces, and as a result, overgrowths in the clay-free aeolian units of the Lower Bunter Sandstone may be more common than recognized. Discrete crystals of authigenic quartz were not observed.

The overgrowths are individual crystallites which have the typical rhombohedral and prismatic projections (plate 2G), described by Waugh (1970) and Pittman (1972). Larger overgrowths coalesce, and in a few cases, form a meniscus which cements an adjacent grain. Overgrowths are generally $5-20 \mu \mathrm{m}$ thick but occasionally obtain sizes up to $40 \mu \mathrm{m}$. Larger quartz overgrowths, between $60-90 \mu \mathrm{m}$, have also been observed (plate 1A), but these are rounded, have unusually thick and irregular clay linings on detrital and overgrown surfaces and may be attributed to second-cycle grains, perhaps from a Permian source. Small idiomorphic facets, less then $10 \mu \mathrm{m}$, are rarely noted forming on these surfaces.

The quartz overgrowths project from both clean and clayey grain surfaces. The overgrowths themselves may or may not be lined by a reddish, tangential iron-oxide stained clay. The common association between quartz overgrowths and this clay suggests that the two events occurred simultaneously and rather early in the diagenetic history of the sediment. Some examples of quartz cementation in association with other, laterformed authigenic minerals however, (ie. analcime), indicates that there have been at least two generations of quartz authigenesis.

Alteration of authigenic quartz was rarely observed. Only one clear example of carbonate corrosion upon a quartz overgrowth was noted in thin section and no unequivocal signs of secondary quartz dissolution were seen with the SEM.

\section{Feldspars}

$10-40 \%$ of the feldspars in any given sample may exhibit overgrowths, but they are volumetrically insignificant and contribute less than $0.5 \%$ to the rock volume. 
The overgrowths, which range in size from 5-30 $\mu \mathrm{m}$, are sometimes recognized by a rhombohedral outline which is commonly developed parallel to the long grain axis and may show the typical hacksaw-like terminations described by Waugh (1978), (plates 2H, 3A). The overgrowths have only been observed growing into primary poreroom; no examples of authigenic feldspar in leached grains were noted. Furthermore, no discrete authigenic feldspars have been observed in the investigated materials.

Both Na- and K-rich overgrowths are present. Albitic overgrowths appear to be slightly more common than K-feldspar overgrowths, but in any case, the occurrence of both $\mathrm{K}$ - and Na-overgrowths contrasts with the observations of Waugh (1978) who noted only a single plagioclase overgrowth in an extensive study of British Permo-Triassic sandstones.

Microprobe analyses of plagioclase overgrowths reveal nearly stoichiometric $\mathrm{NaAlSi}_{3} \mathrm{O}_{8}$ with an Na-mole percent between 98.8-100.0. This pure end-member composition is found irregardless of the host detrital plagioclase composition which varies from andesine $\left(\mathrm{Ab}_{39.7} \mathrm{An}_{58.2} \mathrm{Or}_{1.8}\right)$ to oligoclase $\left(\mathrm{Ab}_{82.2} \mathrm{An}_{12.9} \mathrm{Or}_{4.8}\right)$. Microanalyses have also shown that slightly less pure albitic compositions have been found as skeletal relicts both as rims and within the center of strongly leached grains. As textural relationships suggest that these albites cannot be overgrowths, and no signs of active albitization have been recognized in these samples, it is likely that they are relicts of detrital grains rather than discrete authigenic albite crystals. Recently, Helmold and van de Kamp (1984) showed that albite overgrowths have a purer end-member composition than detrital albite rims and partially dissolved albite grains.

Microprobe analyses of $3 \mathrm{~K}$-feldspar overgrowths yield an average composition of $\mathrm{SiO}_{2} 63.66 \%, \mathrm{Al}_{2} \mathrm{O}_{3}$ $17.92 \%$ and $\mathrm{K}_{2} \mathrm{O} 16.13 \%$, corresponding to mole percents of $\mathrm{Ab}_{28} \mathrm{An}_{0.2} \mathrm{Or}_{97.1}$. Average molecular proportions of 5 detrital $\mathrm{K}$-feldspars are $\mathrm{Ab}_{10.6} \mathrm{An}_{0.6} \mathrm{Or}_{88.6}$. Thus, although the overgrowths are clearly closer to end-member $\mathrm{KAlSi}_{3} \mathrm{O}_{8}$ than the detrital grains, they are significantly less pure than the $\mathrm{K}_{0.992-0.998} \mathrm{AlSi}_{3} \mathrm{O}_{8}$ mole percent overgrowths presented by Ali and Turner (1982) for Triassic sandstones in central England.

As was the case for authigenic quartz, feldspar overgrowths have either been precipitated on pore-linings consisting of iron-oxide stained clays or directly onto the surface of the detrital grain. In detail, the overgrowths may be mixed with this reddish clay, indicating that feldspar authigenesis and iron-oxide/clay lining precipitation occurred simultaneously. It has not been possible to determine any sequential relationships between $\mathrm{Na}$ - and $\mathrm{K}$ - feldspar overgrowths.

Despite the often altered and leached nature of the detrital feldspars, the overgrowths appear to be relatively fresh. However, late stage carbonate and an- hydrite cements may corrode and replace both the detrital feldspar grains and their overgrowths.

\section{Carbonate}

Carbonates are found in nearly every sample, averaging $6.0 \%$ and having abundances up to $10 \%$. In a single case (not averaged), an extensive calcite cement, suggestive of a calcrete, is found at $1150 \mathrm{~m}$ depth.

Both calcite and non-ferroan dolomite have been identified, filling pore space and replacing detrital grains as well as authigenic phases. Carbonate itself may be replaced by anhydrite but is otherwise unaltered. With the exception of ooids and very rare shell fragments, detrital carbonate is difficult to confirm. Although several of the larger dolomite grains are found with some of the sorting and morphological characteristics suggestive of primary (allogenic) grains which were discussed by Sabins (1962), these same rhombs often display clear replacement fabrics and sharp edges indicative of secondary formation.

Carbonates are found in a number of textural forms. Calcite is observed as (1) pore-filling drusy crystals growing radially from ooid margins, (2) irregularly shaped grain replacement fabrics and (3) poikilotopic domains cementing relatively large areas. Dolomite is noted as (1) small (ca. $30 \mu \mathrm{m}$ ), scattered, pore-filling rhombs, (2) similar small rhombs commonly associated with red, iron-oxide stained clay and (3) larger (100$200 \mu \mathrm{m})$ replacement rhombs.

Perfect rhombohedral and scalenohedral forms (dogtooth and nailtooth spar), are commonly radially developed from the margins of ooids and shell fragments (plate 2D). The crystals are 10-40 $\mu \mathrm{m}$ in length and in rare cases, may reach sizes up to $150 \mu \mathrm{m}$ and coalesce with drusy growth on adjacent ooids to form an extensive pore-filling cement. The drusy growth may be found on any type of ooid; tangential or radial, whole or fractured, leached or fresh.

Calcite is rather corrosive upon all earlier phases and partially or totally replaces many of them. The calcite cement often attains a poikilotopic character.

Dolomite occurs only as well-formed rhombohedra. Pore-filling rhombs have a uniform size around $30 \mu \mathrm{m}$ and are found as single, clean idiomorphic crystals which are scattered throughout the sandstones. They are especially found in association with analcime (plate 3B) and may be found in both primary and secondary pores. Fig. 6, based on bulk mineralogical X-ray data, shows the positive correlation between these two phases. Similar-sized dolomite rhombs are often associated with the detrital, reddish, hematitic clays so characteristic of the formation. X-ray diffraction data shows that dolomite is concentrated in the clayey beds and petrographic studies further illustrate how dolomite 


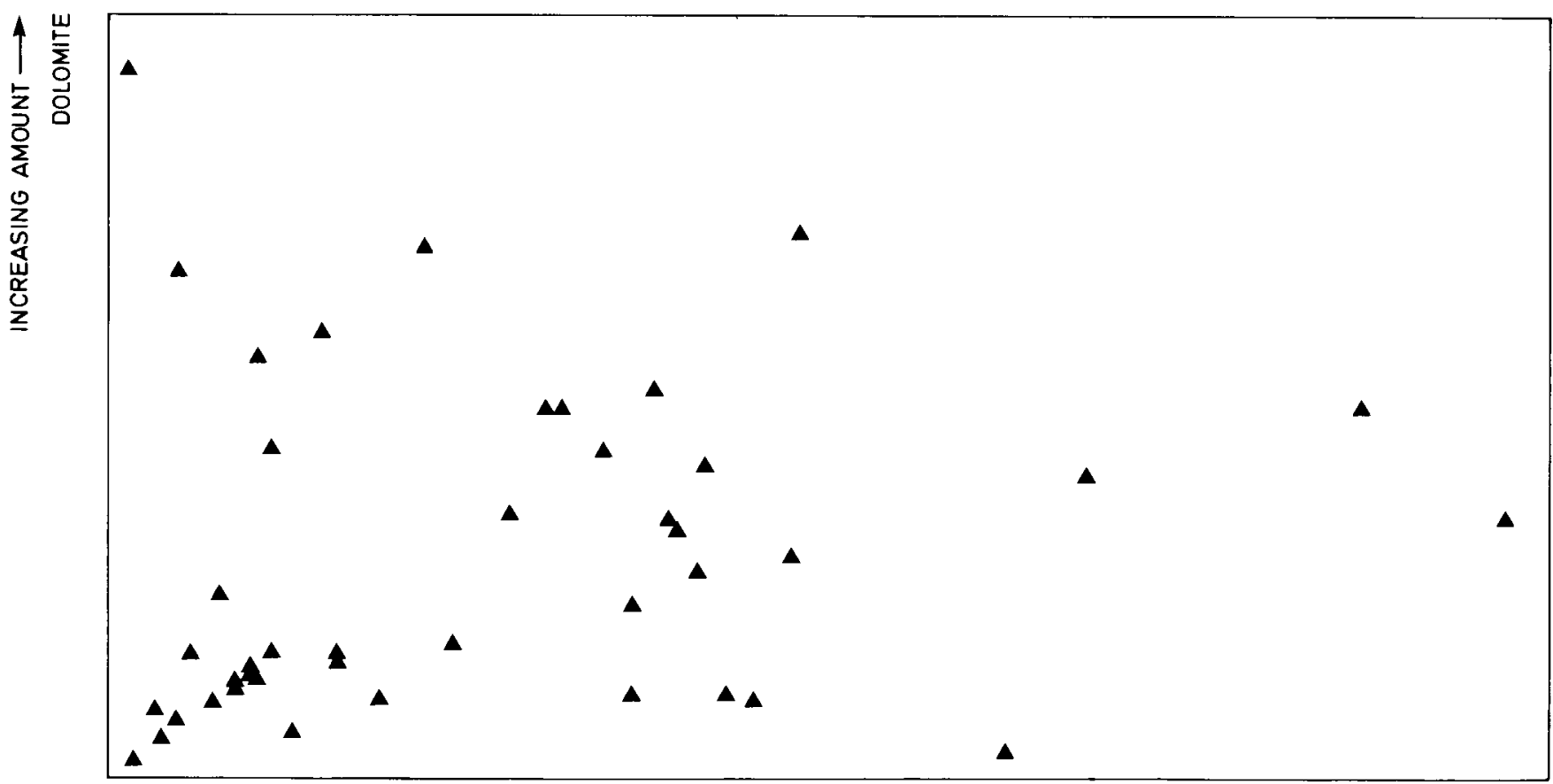

ANALCIME

INCREASING AMOUNT

Fig. 6. Correlation between dolomite and analcime, based upon bulk mineralogical X-ray data. Point-counts show a similar trend.

rhombs are often concentrated in the red claystone intraclasts found in the sandy intervals (plates $1 \mathrm{G}$ and $2 \mathrm{~F})$. Although dolomite rhombs are not always found in these rip-up clasts, it is nonetheless noteworthy that they are so consistently found together with hematitic clay and not, for example, with other authigenic clays (ie. greenish, altered rock fragments or seriticized feldspars). The presence of many small red-clay stained dolomites can be used to identify intragranular porosity resulting from the dissolution of claystone intraclasts.

Larger dolomite rhombohedra are also observed. Some, clearly resulting from replacement, have a rounded, red-clay stained core indicative of an unknown precursor (plate $1 \mathrm{H}$ ), but in other rhombs, signs of replacement may be missing. In any case, the dolomite may be marginally corrosive on any number of detrital fragments and, in some cases, the overall rhombic form may encapsule several grains. Rarely, a large dolomite is noted marginally replacing an ooid, the presence of drusy calcite growth on both sides of the replacing rhomb suggests that calcite authigenesis followed dolomite replacement.

The distribution of replacement carbonate relative to pore-filling carbonate indicates that calcite has no preference for either mode whereas dolomite seems mostly to occur as a replacement product. Thus, calcite is more likely to have a greater effect on porosity reduction than dolomite.

Carbonates were distinguished petrographically by staining techniques and selected samples were then fur- ther studied by electron microprobe analysis. 45 analyses of 12 samples from 6 wells reveals that both calcite and dolomite have remarkably uniform compositions, regardless of origin (ooid, cement) or textural fabric (pore-filling, replacing). There were no signs of zoning. Data is summarized in table 4.

These carbonates are closer to end-member compositions than those described by Boles (1978) for the Tertiary Wilcox Group and appear to be rather similar to the calcites and dolomites presented by Burley (1984) for Triassic sandstones from Cumbria, England. It should be noted however, that unlike Burley's material, no ferroan calcites or dolomites were found in this study.

\section{Analcime}

Analcime occurs as an authigenic phase in amounts up to $4.7 \%$. The difficulty in recognizing this mineral in thin section however, when coupled with its common occurrence in nearly all bulk samples analyzed by $\mathrm{XRD}$, suggests that it is more abundant than the pointcounted values indicate. Fuchtbauer (1967) reports the occurrence of up to $15 \%$ analcime in the middle Buntsandstein but analcime is not mentioned in studies of time-equivalent Triassic sediments from the United Kingdom (Waugh 1978, Colter \& Ebbern 1978, Burley 1984, Knox et al., 1984).

Analcime is found as single, euhedral to subhedral 
pore-lining trapezohedra from $10-80 \mu \mathrm{m}$ in size, as semi-poikilotopic pore-filling crystals up to $300 \mu \mathrm{m}$ and, when seen in clays, also as large vuggy infillings (plates $3 \mathrm{~B}, 4 \mathrm{~A}$, and $4 \mathrm{~B}$ ). It is commonly seen lining secondary pores, especially those due to the leaching of intraclasts or clay-replaced grains, but it may also line primary intergranular pores, often for example, from the margins of ooids (plate 1E). An intimate association between analcime and pore-filling dolomite rhombs is also observed (plate $3 \mathrm{C}$ ), indicating that these two phases formed simultaneously. Van Houten (1962), described dolomite rhombs in association with analcime, precipitated in shrinkage cracks from the redbed Upper Triassic Lockatong Formation, U.S.A.

Analcime generally has a clear appearance although it may occasionally encapsule reddish clots of clay. This clay may be flocculated detrital debris, either from matrix or leached grains, which was incorporated into analcime during its later precipitation.

Alternatively, the clay may be relicts of a replacement process from which analcime formed directly. No clear signs of corrosion or replacement by analcime are observed and although analcime itself is often strongly corroded (plates 1E, 4A), these skeletal shaped analcime grains commonly abut empty poreroom and no leaching agent is obvious. In plate $3 \mathrm{D}$, a clay lining is

\begin{tabular}{|c|c|c|c|c|c|c|}
\hline Calcite & $a$ & $b$ & $c$ & $d$ & $e$ & $f$ \\
\hline $\mathrm{CaO}$ & 51.07 & 53.31 & 54.06 & 51.93 & 54.03 & 55.14 \\
$\mathrm{MgO}$ & 0.19 & 0.34 & 0.51 & 0.89 & 0.99 & 0.17 \\
$\mathrm{FeO}$ & 0.80 & 0.00 & 0.33 & 0.18 & 0.17 & 0.05 \\
\hline
\end{tabular}

a Ooid core, partially leached, Honning 1

b Drusy growth on same ooid, Hønning 1

c Poikilotopic, pore-filling, Rødby 1

d Replacing, Helgoland

Ooid core, Tonder 4

4 Drusy growth on same ooid, Tonder 4

Average calcite ( 34 analyses): $\mathrm{Ca}_{0.96} \quad \mathrm{Mg}_{0.02} \mathrm{Fe}_{0.01}$

\begin{tabular}{|c|c|c|c|}
\hline Dolomite & $\mathrm{a}$ & $\mathrm{b}$ & $\mathrm{c}$ \\
\hline $\mathrm{CaO}$ & 31.66 & 30.06 & 30.80 \\
$\mathrm{MgO}$ & 20.12 & 18.96 & 19.55 \\
$\mathrm{FeO}$ & 0.38 & 0.39 & 0.38 \\
\hline
\end{tabular}

a Replacement dolomite, Tonder 4

b Dolomite rhomb in claystone interclast, Arnum 1

c Dolomite rhomb in clayey laminae of heterolith Tonder 4

Average dolomite (11analyses): $\mathrm{Ca}\left(\mathrm{Ca}_{0.04} \mathrm{Mg}_{0.86} \mathrm{Fe}_{0.01}\right)$

Table 4. Electron microprobe analyses of carbonates.

\begin{tabular}{|c|c|c|c|c|}
\hline & Arnum 1 & Redby 1 & Tønder 1 & Helgoland \\
\hline $\mathrm{Na}_{2} \mathrm{O}$ & 12.19 & 12.53 & 11.01 & 12.30 \\
\hline $\mathrm{AL}_{2} \mathrm{O}_{3}$ & 20.05 & 20.77 & 21.58 & 20.46 \\
\hline $\mathrm{SiO}_{2}$ & 55.97 & 57.09 & 56.36 & 55.34 \\
\hline
\end{tabular}

Table 5. Electron microprobe analyses of analcime.

seen crossing an analcime crystal. The grain is only corroded inside of this lining and appears fresh to the outside of it. If this analcime has replaced a detrital grain (i.e. plagioclase), then the clay lining and corroded analcime may denote the limits of the original grain and the fresh analcime may represent additional pore-filling growth. Although both calcite and anhydrite may encapsule analcime (plate 4D), it appears that analcime dissolution took place prior to, and not as a result of leaching by these later cements.

Microanalyses of analcimes (table 5) reveal rather uniform compositions and a Si/Al ratio between 2.22 2.37 , well within the range for analcimes of nontuffaceous origin precipitated in saline, alkaline lakes (Hay, 1966, Wilkinson \& Whetten, 1964). Fuchtbauer (1983) mentioned possible zeolite precursors and albite replacement of analcime in the German Buntsandstein but there are no indications in this study that analcime formed from more hydrous or alkaline zeolites nor that albite formed from analcime.

\section{Anhydrite}

Anhydrite averages $4.8 \%$ but is found in amounts up to $22 \%$. It invariably forms poikilotopic domains and in doing so, effectively cements the sediment and eliminates porosity (plate $3 \mathrm{E}$ ). With the exception of halite, it is the last mineral to form and may replace any other detrital or authigenic phase.

Anhydrite also occurs as long prismatic crystals up to several $\mathrm{mm}$ in length, often in a radiating cluster, and always in association with red, hematitic clay. In the sandy samples, these laths are only found inside claystone intraclasts. Both morphological and textural relationships indicate that these are replaced gypsum prisms which originally formed at surface conditions within detrital clay. In some cases, the anhydrite now extends beyond clast boundaries and forms part of an optically continous unit with late diagenetic poikilotopic anhydrite.

As observed by Fuchtbauer (1967), anhydrite cement often shows an affinity for the more coarse-grained laminae and in the investigated sands, the anhydrite commonly displays a strong fabric-controlled orientation which is easily seen on core slabs. Thin section study clearly illustrates that this anhydrite is a late di- 
agenetic event. Indeed, early poikilotopic gypsum or anhydrite cement is neither seen in the sandy fluviatile nor aeolian intervals, which is somewhat surprising for sediments deposited under desert conditions (Kessler, 1978). Burley (1984) recorded no more than $2 \%$ sulphates in fluviatially-dominated Triassic redbeds from the U.K., hut he found higher amounts in confined basins from the English Midlands and Southern North Sea (pers. comm.).

Anhydrite commonly contains relicts of reddish clay, ooids or analcime (plates 4C, 4D). Anhydrite itself does not display signs of dissolution.

\section{Barite}

Small, rare, scattered grains of barite have been identified by EDS analysis during SEM study. The grains form fresh, well-developed pore-filling crystals (plate $3 \mathrm{~F}$ ). It has not been possible to determine their time of formation, but late authigenic barite occurs in amounts less than $1 \%$ in the German Middle Buntsandstein (Fuchtbauer, 1967).

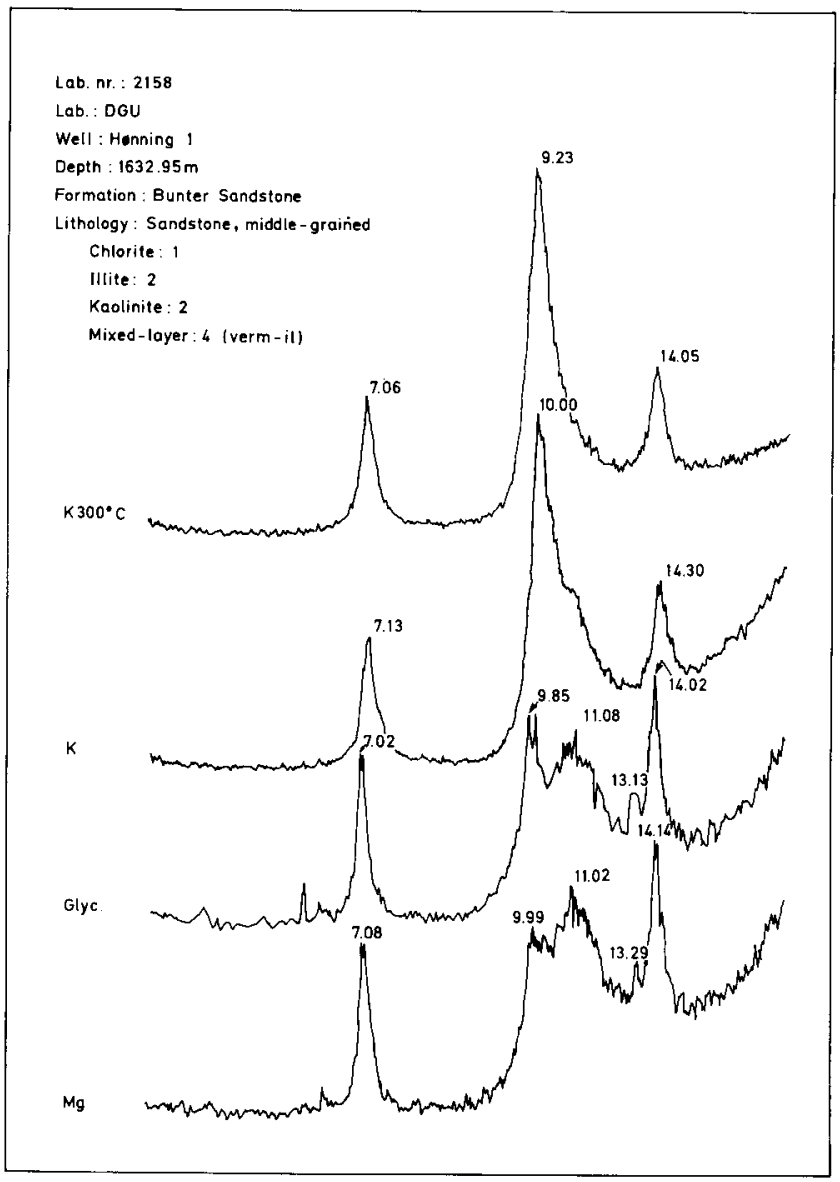

\section{Clays}

The distinction between detrital and authigenic clays has been most problematic and neither thin section, SEM, XRD nor microprobe analyses have yielded conclusive results. They are presented as total unspecified clays in table 2 and range from $0.4-20.6 \%$. Clays are found as matrix, intraclasts, grain replacement, porelinings and pore-fillings but flocculation and deformation have often disturbed their textural relationships and the pervasive reddish staining of much clayey material has often masked their optical and morphological character.

Both petrographic and SEM study confirm the tangential orientation of clay on most detrital grain surfaces (plate $3 \mathrm{G}$ ), indicating the presence of infiltrated clay as described by Walker et. al. (1978). These reddish pore-linings do not display a geopedal texture but rather, are concentrated in pits on the grain surface and are thinner at points of grain contract. They reach thicknesses of $20 \mu \mathrm{m}$ in Rødby- 1 and form pore-bridging menisci here (plate 4E), but they are generally much thinner. SEM/EDS study of these linings (plate $3 \mathrm{H})$ suggests that they are probably illitic.

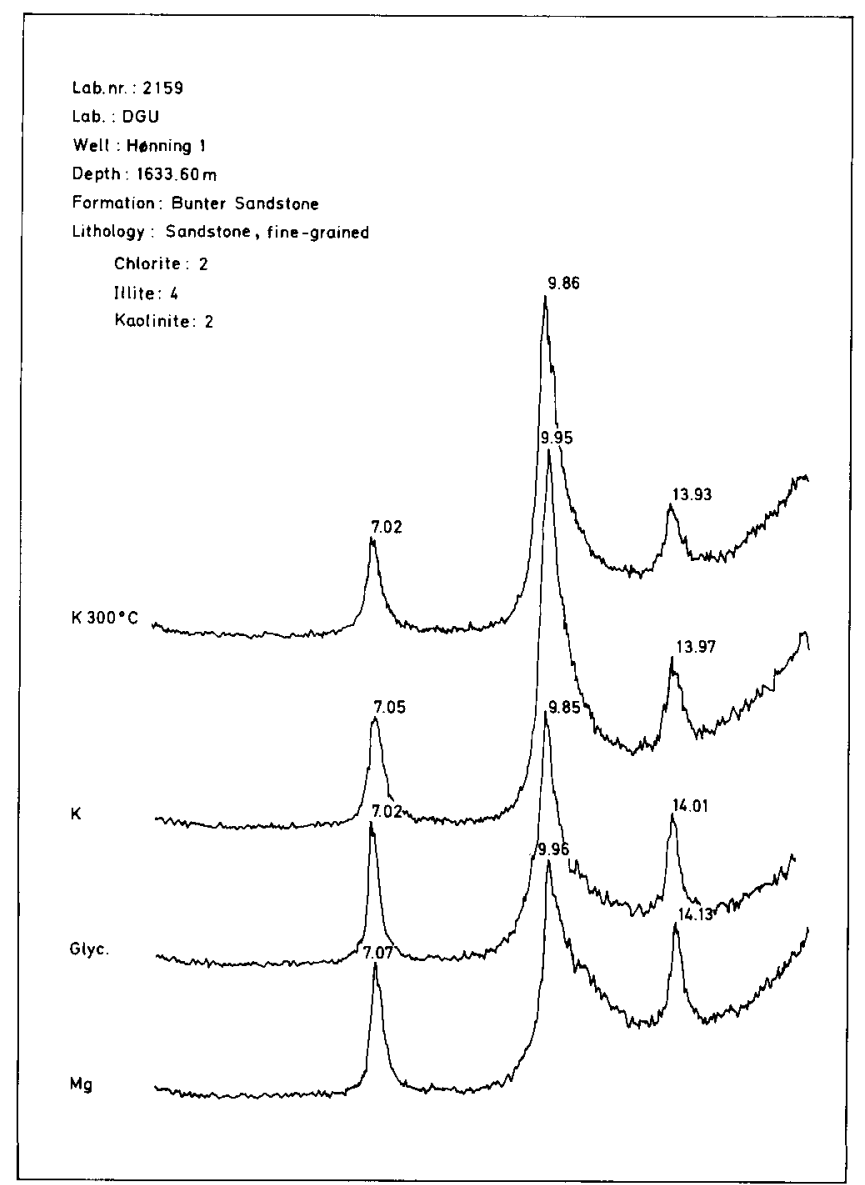

Fig. 7. XRD traces of the $<2 \mu \mathrm{m}$ oriented clay fraction from two sandstones in the Hønning-1 well. Note the abundance of mixedlayer clay in the coarser-grained sample. 
In partially-replaced grains, it is fairly straightforward to recognize authigenic clays, but rather more difficult to identify them. The problem is obviously compounded in totally replaced grains, particularly those of ferromagnesian origin which tend to be strongly hematite-stained. Authigenic clay replacement tends to occur peripherally or along planes of weakness such as cleavages or intergrain contacts in rock fragments.

Alteration of feldspar by sericite is common and microprobe analyses of plagioclase grains confirmed a higher potassium content in the sericite altered areas. Sericitization may take place pre-depositionally, however, and except for arbitrary indicative criteria such as size of sericite flakes and presence of associated miner- als like epidote, the time of sericite formation cannot be more precisely determined. In general, SEM study failed to reveal any diagnostic morphologies for replacement clays, although a boxwork texture (chlorite?) is presented in plate $5 \mathrm{~A}$, a possible crenulated smectite is noted in plate 5B and a single example of kaolinite is seen in plate $5 \mathrm{C}$. High contents of $\mathrm{Mn}$ and $\mathrm{Ti}$ in some clays may be indicative of replaced ferromagnesian minerals. Microprobe analyses are also difficult to interpret, as unacceptable stoichiometric formulae for postulated clay minerals result and it must therefore be assumed that these analyses reflect a mixture of relict grain, iron oxides and authigenic clay.

Thirty-five X-ray diffraction analyses on $<2 \mu \mathrm{m}$ sep-

\begin{tabular}{|c|c|c|c|c|c|c|c|c|c|}
\hline $\begin{array}{l}\text { Sample } \\
\text { number }\end{array}$ & $\begin{array}{l}\text { Well } \\
\text { name }\end{array}$ & $\begin{array}{c}\text { Depth } \\
\text { (meter) }\end{array}$ & Illite & Chlorite & Kaolinite & Vermiculite & Smectite & Mixed-layer & Facies \\
\hline $2188 \mathrm{R}$ & Helgoland & 0.00 & 3.0 & 3.0 & 2.0 & & & & 5 \\
\hline $2190 \mathrm{R}$ & Helgoland & 0.00 & 4.0 & 2.0 & 2.0 & & 1.0 & & 2 \\
\hline $2160 \mathrm{R}$ & $\mathrm{R} ø \mathrm{dby}-1$ & 1151.78 & 4.0 & 1.0 & 2.0 & & & 2.0 & 4 \\
\hline $2161 R$ & $\mathrm{R} ø \mathrm{dby}-1$ & 1198.00 & 3.0 & 1.0 & 2.0 & & & 2.0 & 2 \\
\hline $2162 R$ & Rødby-1 & 1367.78 & 3.0 & 2.0 & 2.0 & 1.0 & & 2.0 & 4 \\
\hline $2155 R$ & Arnum-1 & 1440.48 & 3.0 & 2.0 & 2.0 & & & 2.0 & 4 \\
\hline $2156 \mathrm{R}$ & Arnum-1 & 1442.98 & 2.0 & 2.0 & 2.0 & & & 3.0 & 4 \\
\hline $2157 \mathrm{R}$ & Arnum-1 & 1444.18 & 3.0 & 2.0 & 2.0 & 1.0 & & 2.0 & 4 \\
\hline $2154 \mathrm{R}$ & Aabenrå-1 & 1569.33 & 4.0 & 1.0 & 2.0 & 2.0 & & & 2 \\
\hline $2158 \mathrm{R}$ & Hønning-1 & 1632.95 & 2.0 & 1.0 & 2.0 & & & 4.0 & 4 \\
\hline $2159 \mathrm{R}$ & Hønning-1 & 1633.60 & 4.0 & 2.0 & 2.0 & & & & 4 \\
\hline $2163 \mathrm{R}$ & Tønder-3 & 1657.00 & 2.0 & 2.0 & 2.0 & 2.0 & & 2.0 & 4 \\
\hline $2164 R$ & Tønder-3 & 1671.30 & 4.0 & 2.0 & 2.0 & & & & 5 \\
\hline $2165 \mathrm{R}$ & Tønder-3 & 1675.26 & 3.0 & 2.0 & 2.0 & 1.0 & & 2.0 & 4 \\
\hline $2166 \mathrm{R}$ & Tønder-3 & 1795.00 & 3.0 & 2.0 & 2.0 & 1.0 & & 3.0 & 5 \\
\hline $2167 R$ & Tønder-3 & 1806.05 & 3.0 & 2.0 & 2.0 & 1.0 & & 3.0 & 5 \\
\hline $5022 \mathrm{R}$ & Tonder-4 & 1624.23 & 4.0 & 2.0 & & & & 2.0 & 3 \\
\hline $5023 R$ & Tønder-4 & 1627.96 & 4.0 & 3.0 & & & & 2.0 & 2 \\
\hline $5025 \mathrm{R}$ & Tønder-4 & 1637.73 & 4.0 & 3.0 & 2.0 & & & 2.0 & 4 \\
\hline $2168 \mathrm{R}$ & Tønder-4 & 1658.15 & 2.0 & 2.0 & 2.0 & 2.0 & & 2.0 & 4 \\
\hline $5030 \mathrm{R}$ & Tønder-4 & 1664.56 & 4.0 & 3.0 & 3.0 & & & 3.0 & 4 \\
\hline $2169 \mathrm{R}$ & Tønder-4 & 1667.80 & 2.0 & 2.0 & 2.0 & 1.0 & & 2.0 & 5 \\
\hline $5032 \mathrm{R}$ & Tønder-4 & 1674.46 & 3.0 & 3.0 & & 1.0 & & 3.0 & 4 \\
\hline $5033 R$ & Tønder-4 & 1676.73 & 4.0 & 3.0 & & & & 1.0 & 2 \\
\hline $5037 \mathrm{R}$ & Tønder-4 & 1692.93 & 4.0 & 2.0 & & & 1.0 & 2.0 & 3 \\
\hline $5039 \mathrm{R}$ & Tønder-4 & 1768.40 & 4.0 & 3.0 & 1.0 & 2.0 & 1.0 & 1.0 & 4 \\
\hline $2170 \mathrm{R}$ & Tønder-4 & 1768.40 & 4.0 & 1.0 & 2.0 & 2.0 & & & 2 \\
\hline $2171 \mathrm{R}$ & Tønder-4 & 1776.50 & 3.0 & 2.0 & 2.0 & 2.0 & & & 3 \\
\hline $5041 \mathrm{R}$ & Tønder-4 & 1780.10 & 4.0 & 3.0 & & & 1.0 & 1.0 & 2 \\
\hline $5000 \mathrm{R}$ & Tønder-5 & 1734.48 & 4.0 & 4.0 & & & & & 4 \\
\hline $5003 \mathrm{R}$ & Tønder-5 & 1734.71 & 4.0 & 4.0 & & & & & 4 \\
\hline $5006 \mathrm{R}$ & Tønder-5 & 1742.80 & 4.0 & 2.0 & & & & & 2 \\
\hline $5010 \mathrm{R}$ & Tonder-5 & 1864.50 & 4.0 & 3.0 & & & & 1.0 & 4 \\
\hline $2172 \mathrm{R}$ & Tønder-5 & 1871.55 & 5.0 & 2.0 & 2.0 & & & & 5 \\
\hline $5015 \mathrm{R}$ & Tønder-5 & 1886.20 & 2.0 & 3.0 & & & & 1.0 & 3 \\
\hline Average: & & & 3.4 & 2.3 & 2.0 & 1.5 & 1.0 & 2.1 & \\
\hline Interval: & & & $2.0: 5.0$ & $1.0: 4.0$ & $1.0: 3.0$ & $1.0: 2.0$ & $1.0: 1.0$ & $1.0: 4.0$ & \\
\hline
\end{tabular}

Table 6. XRD analyses of the $<2 \mu \mathrm{m}$ clay fraction. The values $1-5$ represents a quantification of each type of clay as a percent of the total clay assemblagc. Based upon relative peak intensities and a specific method of computation (Holger Lindgreen, pers. comm.), the numbers 1-5 represent the following ranges:
1: $<10 \%$ of the total clay assemblage
4: $50-70 \%$
2: $10-30 \%$
5: $>70 \%$.
3: $30-50 \%$ 
arates show that at least six different clay minerals are present (table 6). The assemblage is dominated by illite, followed by chlorite and mixed-layer compositions consisting of various combinations of illite, smectite, chlorite and vermiculite. Lesser amounts of discrete kaolinite, vermiculite and smectite are also recorded. The observed variation in these clay assemblages is illustrated in fig. 7 where two analyses of sandstones within $65 \mathrm{~cm}$ of each other are presented from the Hønning-1 well.

The distribution af clay minerals reported in this study generally corresponds to those described by April (1980) for the Upper Triassic/Lower Jurassic Newark Supergroup of the Connecticut Valley, U.S.A. Furthermore, by analogy with April's work and Turner (1980), it is also seen that the clay mineralogy of the Bunter Sandstone Formation is typical of many other Permo-Triassic sequences.

\section{Iron and titanium oxides}

Although no attempt was made to differentiate between detrital and authigenic opaque minerals in this investigation, numerous studies of redbeds ( Walker 1967, Morad 1983) suggest that ferric oxides/hydroxides are formed diagenetically in an environment similar to that which prevailed during deposition of the Bunter Sandstone. The red color of the sediment is a result of dispersed microcrystalline hematite in the clay, and indeed, crystals of hematite were occasionally identifiable, admixed with the clays. Microprobe analyses of clayey areas show that they contain a significant amount of iron (from $2-5 \% \mathrm{Fe}^{3+}$ ), most of which is probably attributable to minute iron oxide crystallites in association with clay platelets. Finally, pore-filling authigenic titanium oxides (anatase?), up to $30 \mu \mathrm{m}$ in size, were detected by SEM-EDS analysis (plate 5D). Anatase had been commonly recorded in earlier studies of the heavy mineral fractions (Henrik Friis, pers. comm.). Ixer et. al. (1979) have described pore-filling anatase crystals from Triassic redbeds in England.

\section{Halite}

Halite, which may have been derived in three possible ways, is present in the investigated material. These are:
(1) salt from drilling mud, (2) salt precipitated from porewaters at surface temperatures after core recovery and (3) salt formed diagenetically at depth. In some cases, the origin of the salt is obvious (plate 5E), but in many instances it is not and it can be extremely difficult to characterize. Fuchtbauer (1967) discussed similar considerations in a study of the German Buntsandstein. Several salt textures such as the poikilotopic, columnar and small cubic forms described by Whetten (1984) have been recognized by SEM-EDS analysis, but petrographically, salt textures are much more difficult to classify. In all cases, salt is the last phase to form and when present, completely fills remaining poreroom. If not a drilling artifact, it puts considerable constraints upon porewater evolution and obviously plays an important role in any reservoir evaluations.

\section{Porosity}

Porosity, as determined by point counts in the sandstones, ranges from $2-30 \%$ and averages $18 \%$. This is somewhat lower than the average coreplug measured porosity of around $24 \%$ but this difference is at least partially due to uncounted micropores in the clayey material which is admixed with the sands. Gas permeabilities are around $500 \mathrm{mD}$.

Porosity may be characterized as primary or secondary (Schmidt \& McDonald, 1979), but this distinction is not always obvious. Unequivocal examples of secondary intragranular pores are certainly recognizable in leached grains (plates 1C), but the origin of the more abundant intergranular pores (plate $5 \mathrm{~F}$ ) can be more difficult to determine. Oversized pores, due to the complete removal of detrital components have been noted, but grain packing relationships suggest that such pores are more the exception than the rule in the investigated materials.

Burley (1984) reported point-counted total porosities from 1-29\% in lower Triassic redbeds from England. In these samples, grain dissolution porosity ranged up to $8 \%$ of the total volume of the rock and averaged $23 \%$ of the overall porosity. These values compare well with visual estimates for the sandstones in this study and are also in good agreement with general observations by Siebert et. al. (1984) for sandstones such as these containing more than $10-15 \%$ feldspar and rock fragments. 


\section{Diagenesis}

\section{Diagenetic sequence}

The diagenetic history of the Bunter Sandstone Formation is schematically presented in fig. 8 . The chronology was developed by interpreting a large number of textural relationships with the help of thin sections and SEM. As a result of mutual relationships between two or more phases, constraints were defined for various diagenetic events and an overall sequential pattern was formulated. The resulting diagenetic history is rather uniform throughout the investigated region and resembles, in general, that for redbed series described elsewhere (Walker 1967, Fuchtbauer 1967, Turner 1980, Burley 1984).

Diagenesis, as recognized in the Bunter Sandstone Formation, is the result of several processes including infiltration, compaction, framework grain replacement and dissolution, transformation and precipitation and dissolution of authigenic minerals. Since these pro- cesses interact, they overlap in time and it can be difficult or impossible to define specific temporal relationships precisely.

The concept of diagenetic regimes in sandstones (Schmidt and McDonald 1979) can combine several processes and relate them to a specific diagenetic environment. These authors defined three major regimes and related them to either the chemistry of the depositional environment (eogenesis), changes in the subsurface environment during burial (mesogenesis) or changes resulting from the later re-introduction of near-surface conditions after burial (telogenesis). Only the eogenetic and mesogenetic regimes apply here since, with the exception of Helgoland, there is no evidence of any significant post-depositional uplift. In addition, the Bunter Sandstone Formation is comformably overlain by impermeable evaporites of the Ørslev

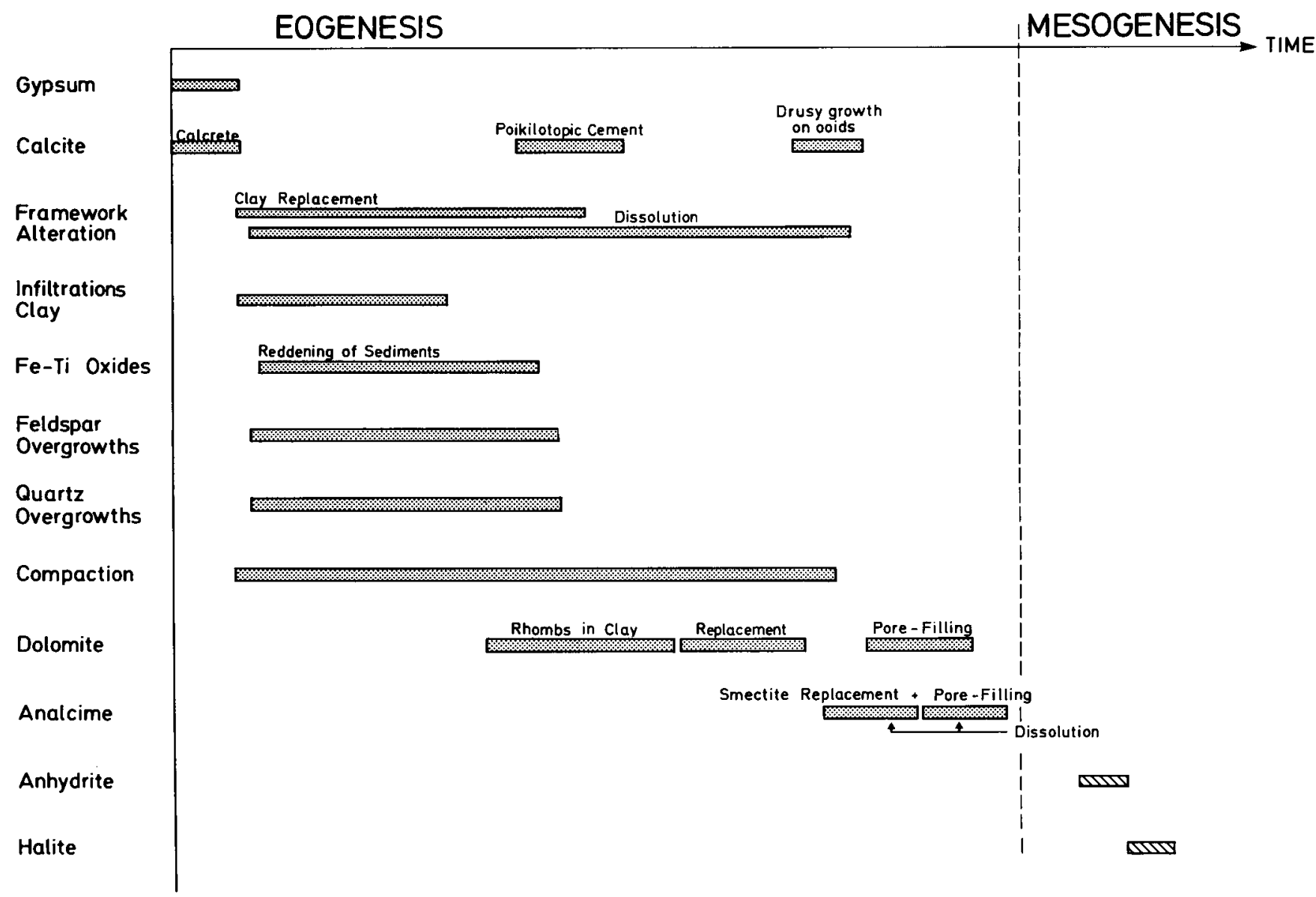

Fig. 8. Diagenetic sequence, Bunter Sandstone Formation. 
Formation (table 1), so any renewed communication with meteoric surface waters would be unlikely unless complete unroofing occurred. The following events are attributed to the eogenetic regime: early gypsum and calcite cements, $\mathrm{Fe}-\mathrm{Ti}$ oxide/hydroxide formation, grain replacement by clay, grain dissolution, infiltrated clays, quartz and feldspar overgrowths and mechanical compaction.

Mesogenesis is defined as the period when interstitial waters are no longer controlled by the surface environment (Schmidt \& McDonald, 1979). This is a useful characterization, but it can be quite difficult to apply in ancient environments. As an example, most secondary porosity is, by definition, generated within the mesogenetic regime (Ibid), and as such, the dissolution of framework components (being the major cause of secondary porosity in the investigated samples), should be dominant at this time. However, the dissolution of framework components such as feldspars and rock fragments, as described in redbeds by Walker (1967) and Walker et al. (1978), are clearly related to highly oxidizing formation waters within the eogenetic environment. As calcite, dolomite, analcime and some clays can be related to depositional brines (see Diagenetic Processes), these authigenic phases should also be placed in the eogenetic regime. Still, textural relationships indicate that they postdated other above-mentioned eogenetic events such as quartz and feldspar overgrowths and most mechanical compaction. In contrast, late-stage cements such as anhydrite and halite are clearly placed within the mesogenetic regime.

\section{Eogenetic regime}

Very early gypsum and calcite cements represent the first diagentic events encountered in the investigated materials. Early calcite has only been noted in a single sample and gypsum is scattered in detrital clays. Both cements however, are common in desert environments where they form in the vadose zone as the sediment dries.

Early calcite cement has only been observed in the Rødby-1 well (plate 4F). The cement has a poikilotopic, displacive character indicative of calcrete and indeed, the lack of pore linings, overgrowths and leaching within the calcrete all suggest that the cement was precipitated very shortly after deposition. These later diagenetic features are commonly seen in other Rødby-1 sandstones. Both minor corrosion and replacement of quartz and feldspar grains by calcite is noted within the calcrete, however.

By analogy with other desert environments, it cannot be excluded that an early halite cement also formed, but went back into solution after burial (Glennie et al. 1978). In claystone core pieces, cubic-shaped impressions after halite? may be evidence of this.
Once the sediments are buried below the water table, another series of diagenetic events begins in the phreatic zone. Clay infiltration is the initial event, but it overlaps with several later processes. Flooding onto the initially dry floor of the desert basin will lead to rapid downward percolation of muddy water which either filters the clay at low permeable horizons or deposits it onto grain surfaces upon reaching the water table. Periodic recharge into the basin could lead to several generations of clay which may line detrital grain surfaces, be intermixed with contemporaneously forming overgrowths or coat the overgrowths themselves.

Walker (1976) noted that detrital silicate minerals, including ferromagnesian minerals as well as feldspars, undergo two types of intrastratal alteration: (1) replacement by clays and (2) dissolution. In practice, these processes are intimately associated and grains which suffered clay-replacement as well as dissolution are very common. Walker et al. (1978) stated that both alteration sequences are possible, but cautioned that preservation is likely only when replacement is followed by dissolution. As a result of aridity in desert basins, unstable silicate minerals could be expected to survive transport and surface weathering (Walker 1976) and labile grains also appear to have been present in the original detrital assemblage of the Bunter Sandstone Formation (plate 4G). Although some clay/sericite replacement of detrital grains is probably prediagenetic, clay replacement and dissolution first became significant after deposition, when the grains were continually bathed in intrastratal solutions. That the replacement and dissolution of these grains is mostly diagenetic is exemplified by the nature of the grain-clay textures. Leaching occurs along zones of weakness in the grain (plates $1 \mathrm{C}, 2 \mathrm{~B}, 2 \mathrm{C}$ ) which, due to its resulting fragility, could not have undergone later transport without loss of original morphology. As a result of increasing compaction during burial, the replacement clay may mix with the interstitial matrix and become difficult to recognize.

Figure 9 indicates that the mixed-layer clays are somewhat more common in sandstones than in finergrained sediments. This could suggest that labile ferromagnesian grains, which are more abundant in the sandstones, were preferentially altered to a mixedlayer composition. SEM study showed possible smectitic morphologies and X-ray as well as microprobe analyses indicated compositions suggestive of illitesmectite/chlorite/vermiculite mixed-layer? clays. Walker et, al (1978) stated that replacement clays from desert environments in the southwestern U.S.A. are dominantly mixed-layer illite-montmorillorites and Burley (1984) suggested that replacement clays in Lower Triassic redbeds from the U.K. probably have an illite-smectite mixed-layer composition. Jeans (1978), in a detailed study of Triassic clay assemblages in Europe, suggested that in addition to the detrital ma- 


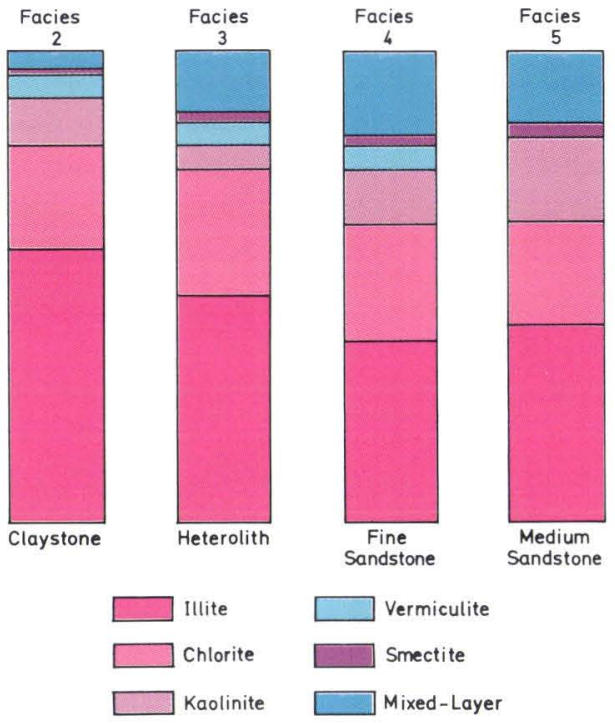

Fig. 9. Distribution of clays in relation to lithofacies. Specific clay mineral abundances were quantified based on relative peak intensities of the total clay assemblage as measured on diffractograms. These relative intensities were presented on a $1-5$ scale representing increasing percental ranges $(10-30 \%$, $30-50 \%$, etc.). These abundances are plotted for each clay type within the individual facies and normalized to balance out the effect of different number of samples in each facies. The distribution of each clay type is thus plotted as percent occurrence within each lithofacies.

Note that illite comprises close to, or more than, half of the total clay assemblage in all facies and that chlorite is generally the next most abundant clay mineral in all facies. Note too, that mixed-layer clay increases in importance in sandstones (facies $4+5)$ and smectites and vermiculites decrease in these facies.

trix assemblage of mica and chlorite found in all samples, there may also be a more restricted exotic assemblage consisting of a number of $\mathrm{Mg}$ - rich clays such as smectite, smectite/chlorite, smectite/mica, corrensite, chlorite and palygorskite. He provided several examples of the diagenetic origin of these clays and stated that they were not transformation products of the detrital chlorites and micas.

The continual bathing of iron-bearing minerals in the strongly oxidizing intrastratal waters of the desert environment also leads to the development of hematite and consequent reddening of the sediments (Walker 1967). As a result, the authigenic clays forming simultaneously in this environment should also be pigmented like the detrital clays. This is especially true for altered ferromagnesian grains, which often have a strong reddish stain, but replaced feldspars, for example, may be essentially unstained. This may suggest that reddening ceased before replacement of these feldspars.

Titanium is mobilized together with iron, so the formation of authigenic anatase, discussed on page 25 probably occurred around this time. No textural evidence was found to relate this to other events but Zim- merle (1982) noted that newly formed titanium minerals such as rutile and anatase generally form early and prior to secondary silica.

Although both quartz and feldspar overgrowths are present, textural relationships between these two cements were never observed and it has been impossible to determine which formed first. Fuchtbauer (1967) and Mader (1981) in their studies of the German Buntsandstein, observed that feldspar authigenesis generally preceded quartz but Kessler (1978) stated that quartz overgrowths are probably earlier than feldspar overgrowths in his investigation of desert sandstones. A simultaneous origin for both cements is not unreasonable.

Constraints can be placed on the timing of these overgrowths relative to other events. First, their association with infiltrated clay linings indicates that they must also represent an eogenetic event. Second, the absence of authigenic feldspar inside leached feldspar grains strongly suggests that dissolution of detrital feldspar generally postdated overgrowths and the corrosion occasionally noted on feldspar overgrowths further substantiates this. In contrast, most quartz overgrowths are generally unaltered, even though detrital quartz grains show signs of marginal corrosion. A second generation of quartz authigenesis may also have occurred after leaching as noted by the fresh overgrowth on the altered quartz? grain in plate $5 \mathrm{G}$ and by the textural relationship with analcime in plate $4 \mathrm{H}$. It may be that the first generation of quartz overgrowths was volumetrically very small and corrosion is difficult to detect on the few clay-coated surfaces.

Compaction of the investigated materials has been modest. Grain contacts are mostly tangential to long (plate 5F), and porosities average around 20\%. At least $5 \%$ absolute of this value is probably due to secondary porosity (see page 25). If one assumes that around $10 \%$ of the total rock volume is now filled by cement (table 2), then the true intergranular, primary porosity after compaction is estimated to be approximately $25 \%$. Assuming initial porosities around 35\% and permeabilities of $10000 \mathrm{mD}$ for arkosic arenites (Nagtegaal 1978), then the porosity and permability reduction within the Bunter Sandstones generally corresponds to values predicted at depth (Ibid). Loucks et. al. (1981) noted that primary intergranular porosity was dominant in matrix-free sandstones which had been buried to approximately 1800 meters depth.

The fragile relicts resulting from the dissolution of feldspars and rock fragments indicates that any significant amount of mechanical compaction must have occurred prior to leaching. Burley (1984) explained some high porosity zones in otherwise more compacted sand sequences of the Triassic Sherwood Sandstone (U.K.) as possibly being due to the dissolution of a pervasive carbonate cement (ie. calcrete). He noted that these porous zones contain highly corroded quartz grains and 
leached feldspars. Compacted sands were not observed in the Danish sequence yet corrosive features are common. In a more limited study of the Sherwood Sandstone, Knox et al. (1984) felt that pervasive removal of carbonate cement was not necessary to generate porous sands at depth. Given the absence of compacted intervals and the apparent "normal" compaction gradient mentioned above, it is felt that the sandstones in this report still retain high primary porosities. In addition, the absence of pore linings, overgrowths and leached grains within the calcrete in Rødby-1 makes it unlikely that these diagenetic features should be found in porous sands had their porosity also been due to the removal of this early carbonate cement at a later, postcompactive date.

Peripheral carbonate replacement of overgrowths, the absence of clay coatings on authigenic carbonates and cement-packing relationships all suggest that, for the most part, calcite and dolomite formation postdated the earliest diagenetic events. Several phases of carbonate mobilization have taken place, but it is difficult to determine just when any such specific event occurred. An example of this problem is illustrated in plate $5 \mathrm{H}$ where a calcite crystal has grown around some illite fibers of indeterminate origin. In thin section, the observation that calcite sometimes contains reddish clay relicts suggests that calcite may have replaced an earlier clay-replaced fragment (ferromagnesian grain?) or a sedimentary intraclast. In the same way, the common association of small dolomite rhombs in hematitestained clay (plates $1 G, 2 F$ ) may result from the replacement of clay whereas the occurrence of larger dolomite rhombs with a rounded, clay-lined core (plate $1 \mathrm{H})$ may be due to the replacement of some detrital component (Mg-rich pellets?).

Sutured contacts on ooids indicate that some pressure solution and removal of calcite has occurred, but the presence of small sparry crystals inside and outside leached ooid cores indicates that a later stage of calcite precipitation also took place. The thick iron oxide rims noted along pressure solution contacts (plate 1E) may reflect the solubility of $\mathrm{Ca}^{+2}$ as well as the relative immobility of iron in an oxidizing, alkaline environment. The partial dissolution of some ooid cores is probably a local affect attributed to their structural weakness, since other calcites, with similar chemical compositions are uneffected. Thus, although it cannot be excluded that earlier authigenic carbonate phases have been removed, signs of widespread carbonate cement dissolution, as described by Burley and Kantorowicz (1986) have not been observed.

The simultaneous occurrence of analcime and dolomite (plate 3C), enables a more precise diagenetic sequence to be formulated. First, since analcime is commonly seen inside secondary pores resulting from grain dissolution, it obviously postdates clay replacement and dissolution. Second, analcime has also been noted nucleating on ooid margins (plate 1E) where it predates drusy, pore-filling calcite. This suggests that calcite was the final carbonate generated and followed dolomite and analcime authigenesis. In detail however, there have been several generations of calcite and dolomite, from very early calcrete to later pore-filling and replacement carbonates. Both Mader (1981) and Burley (1985) have described several generations of calcite and dolomite diagenesis.

\section{Mesogenetic regime}

Anhydrite is the last certain diagenetic event which affected these sandstones. It is extremely corrosive and can attack all earlier detrital and authigenic phases (plates 4C and 4D), thus making it easy to place anhydrite sequentially. It is more difficult of course, to state the time when early formed gypsum transformed to anhydrite. Murray (1964) documented that the transition occurs at $42^{\circ} \mathrm{C}$ in pure water and at lower temperatures with increasing salinity. Assuming a geothermal gradient of $30^{\circ} \mathrm{C} / \mathrm{km}$, high initial salinities, and increasing salinities with depth, it seems likely however, that the transformation occurred at relatively shallow depths within the mesogenetic regime. Anhydrite is common as a relatively late cement (Heald \& Baker 1977, Hancock 1978), although Fuchtbauer (1967) and Markert \& Al-Shaieb (1984) report that dolomite postdated anhydrite in their respective studies of Triassic and Permian sediments, and Ortiz \& Arti Cabo (1980) reported analcime which was synchronous or later than anhydrite in an evaporitic gypsum-carbonate complex.

Halite has been detected partially filling all remaining pores in several sandstones. From textural relationships it was clearly the last mineral to form, but it shows no reaction with any other phase. Thus, although its diagenetic origin cannot be proven on the basis of this investigation, porewater studies by Troels Laier (pers. comm.) strongly suggest that it formed at depth. Both Fuchtbauer (1967) and Burley (1985) have reported very late stage halite in equivalent Triassic sediments.

\section{Patterns of diagenesis}

\section{Considerations}

The course of diagenesis will be influenced by preburial controls such as depositional environment, provenance and tectonic setting and these, in turn, direct the subsequent interaction of physical, physiochemical and biochemical processes which modify the starting material. Isolation of single factors is extremely complex however, because diagenesis is a dynamic process and the reactive pathways will be continually modified by ongo- 
ing events and the ability of the chemical system to transfer material.

The study of possible relationships between diagenesis and provenance, lithofacies and depth formed part of this investigation and they are discussed below. It is assumed that an arid and oxidizing climate prevailed throughout the region and that, on a megascale, tectonism was similar (ie. no telogenesis, except for Helgoland). In addition, analogy with redbed deposits elsewhere (Walker 1967), suggests that biochemical and organic processes played a negligible early role. Furthermore, there is no evidence that any late-stage, organically-derived fluids have influenced diagenesis in the Bunter Sandstone Formation.

\section{Diagenesis in relation to provenance}

The detrital assemblage is rather uniform throughout the investigated area and there are neither significant mineralogical differences between wells nor are there differences between the upper and lower sandstone units within wells (table 2). The ratios for polycrystalline/monocrystalline quartz and total feldspar/total quartz vary from $0.1-0.3$ and $0.1-0.8$ respectively, but show no predictable regional variation. The ratio plagioclase/alkali feldspar, on the other hand, varies from $0.2-1.8$ and although the amount of spreading is great- est in the Tønder wells, the highest values are found here as well. As the degree of K-feldspar alteration does not appear to be greater in the Tønder wells, it is unlikely that the relatively higher ratios found here are simply due to difficulty in recognizing highly altered alkali feldspars. Rather, the variation is probably locally derived.

Although ooids are found scattered throughout the Bunter Sandstone Formation, they are mostly concentrated in a few aeolian beds of the lower sandstone units. Given their leached character and sutured contacts, together with the observation that the calcite crystals growing from their margins followed compaction and dissolution, it might be expected that the amount of calcite cement was greatest in the ooid-rich samples. Thin section study indicated that this was not the case however, suggesting that while some authigenic calcite was probably remobilized from the ooids, other sources of $\mathrm{Ca}^{+2}$ must have also been available.

Intraclasts are most common in the fluviatile units of the Bunter Sandstone and can be easily compacted to form a pseudomatrix which can reduce porosity. As shown in fig 10 , intraclasts are most abundant in the fine-grained sandstones (facies 4), where they appear to be correlated with lower porosities when found in amounts greater than around $5 \%$. In addition, it should be noted that these fragments contribute clay to what may hydrodynamically be well-sorted sand.

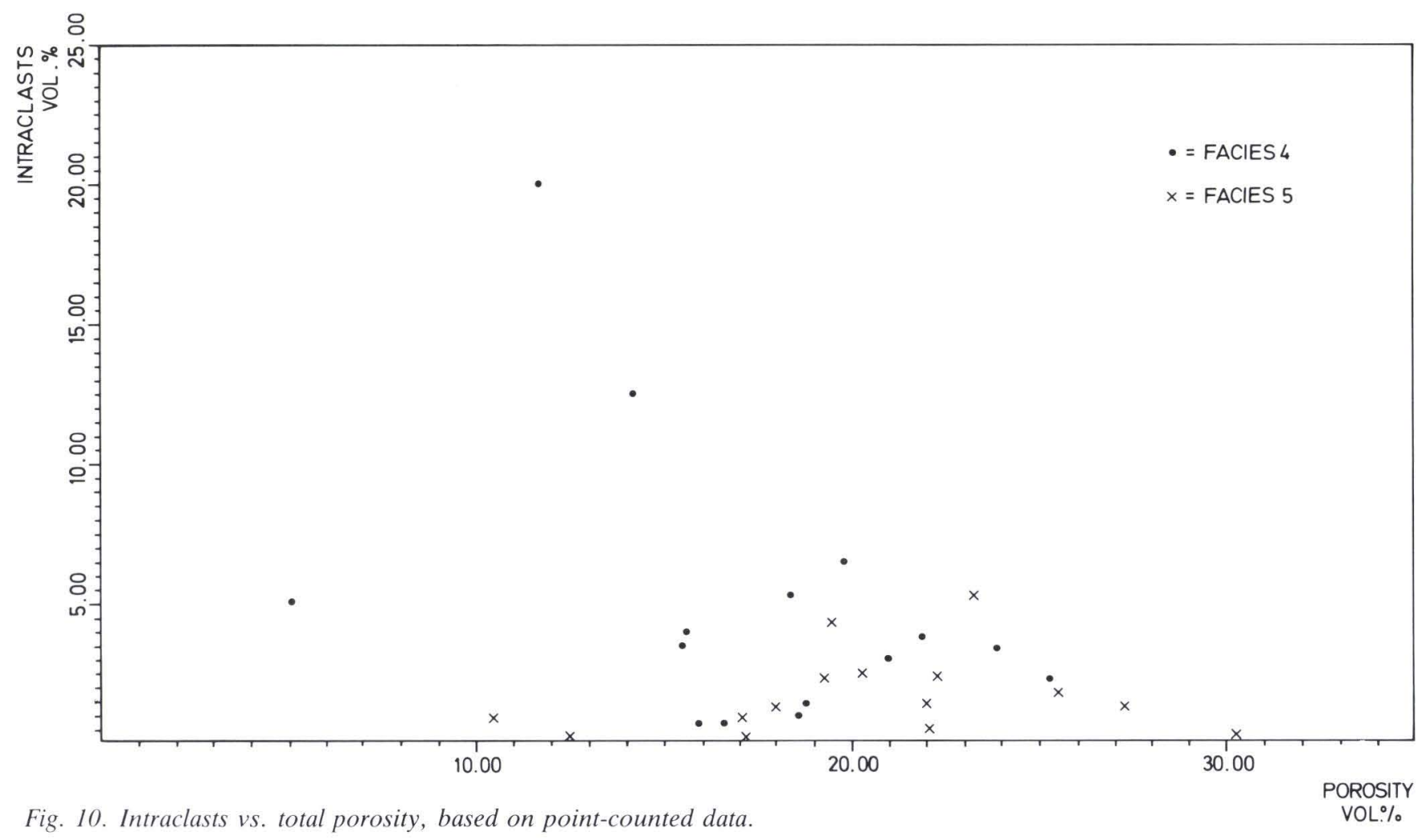




\section{Diagenesis in relation to lithofacies}

Both bulk mineralogical X-ray data as well as petrographic analysis have been used to study the diagenetic assemblages in lithofacies ranging from clay to fine to medium-grained sandstones (facies 2-5). Fig. 11a, based only on $X$-ray data, illustrates the resulting facies-controlled distribution. Calcite, anhydrite and halite are more abundant in the sandstones whereas dolomite and analcime occur in greatest amounts in the claystone and heteroliths.

When petrographic data are considered (fig. 11b), the trends are less obvious. This is due, of course, to the fact that only facies 4-5 (sandstones) were pointcounted in thin section and therefore any facies-controlled differences are likely to be more subtle here. Analcime appears to be most abundant in the finergrained sandstones, but calcite, dolomite and anhydrite show large variations and no preference for either facies. Halite was not point-counted.
Fuchtbauer (1967) noted the prevalence of anhydrite in sandstones and Boles (1978) observed that calcites occur more frequently in sandstones than shales in a study of the Wilcox Formation, U.S.A. The common occurrence of diagenetic dolomite (McHargue \& Price 1982) and analcime (van Houten 1962), both together and in clays, is well-documented.

Fig. 9 illustrates the distribution of the $<2 \mu$ m clay assemblage in relation to facies. Note that whereas the probable detrital clays, illite and chlorite, show no preferred facies distribution, the amount of mixed-layer clays, which are probably of diagenetic origin, clearly increase in sandstones (facies 4 and 5) relative to claystones and heterolithic sands. The other clays show no marked patterns, though it should be noted that the amounts of vermiculite and smectite decrease in the sandstones together with the increase in mixed-layer clays. April (1980) clearly documented the lithological variation in clay mineral distribution in a study of similar sediments from the Connecticut Vally, U.S.A.

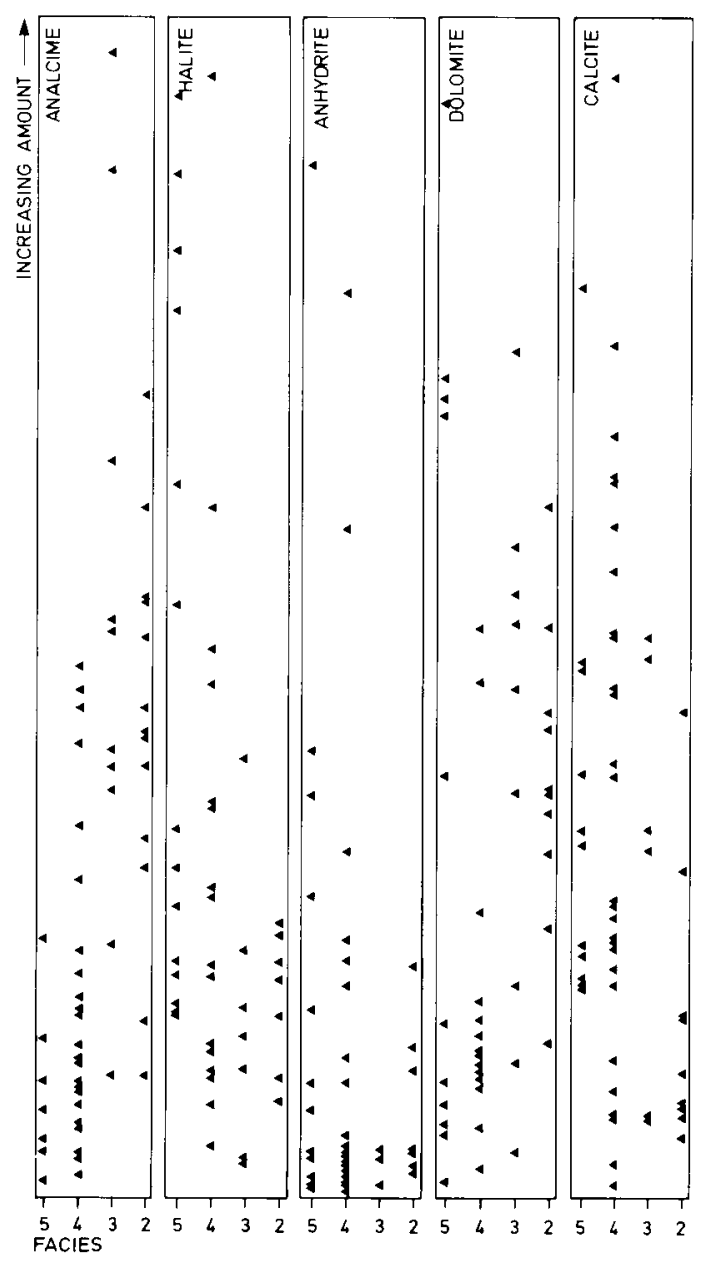

Fig. 11a. Diagenetic minerals in relation to lithofacies, bulk mineralogical $X$-ray data.

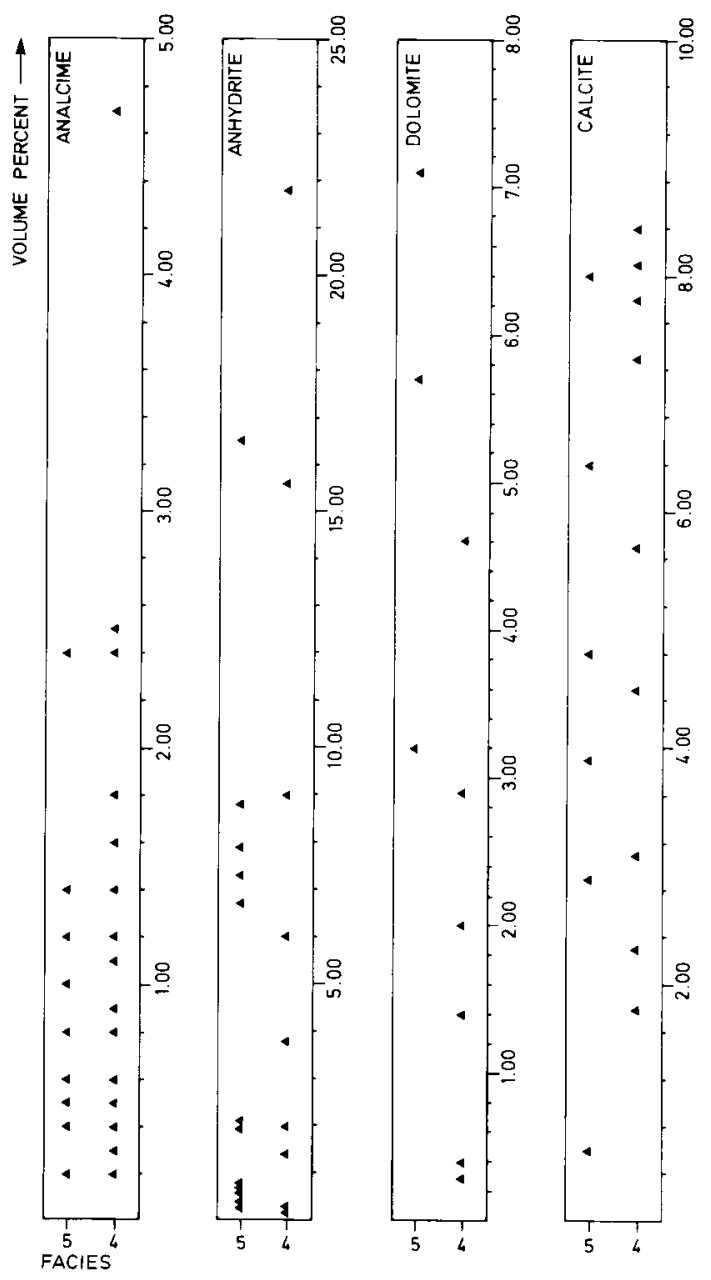

Fig. 11b. Diagenetic minerals in relation to lithofacies, point-counted data. 


\section{Diagenesis in relation to depth}

Temperature and pressure related diagenetic modifications as a response to increasing depth of burial have been amply documented (Parker \& Sellwood 1983, McDonald \& Surdam 1984). Since however, the depth span of the Bunter Sandstone Formation onshore Denmark is only 800 metres and burial depths are less than $2000 \mathrm{~m}$ (fig. 3), depth-related variations in diagenesis are not easily ascertained. Certainly, the diagenetic sequence discussed previously (fig. 8) is contingent upon both depth and time under conditions of constant burial, but as no minerals can be shown to appear or disappear at specific depths, only temporal relationships can be documented.

Neither the degree of mechanical compaction, amount of dissolution nor frequency of replacement appears to show any depth-related patterns. Furthermore, when considering the distribution of the diagenetic minerals as a whole, both thin section and bulk mineralogical X-ray data show large amounts of scatter and uncertain relationships (fig. 12). Nevertheless, it is interesting to note the generally small amounts of halite and anhydrite in the sandstones above 1600 metres.

Unlike calcite, dolomite may show a weak overall increase with depth. Analcime often accompanies dolomite, but does not appear to show any similar tendency. If considered within individual facies however, then analcime is observed to increase with depth within heteroliths and claystones (facies 2 and 3 ) but show no trend within sandstones (facies 4 and 5).

No compositional variation was observed for the carbonates with increasing depth, but this may simply be due to the shallow depths recorded in this investigation. In comparison, Boles (1978) noted an increasing ferroan content with depth and Burley (1984) reported both late ferroan dolomite and ankerite cements in redbeds which were buried to greater than $3 \mathrm{~km}$. On the other hand, Land (1984) noted relatively invariant calcite compositions in the rapidly buried Tertiary Frio Formation over a depth range from 7000-15000 feet (2134-4572 m).
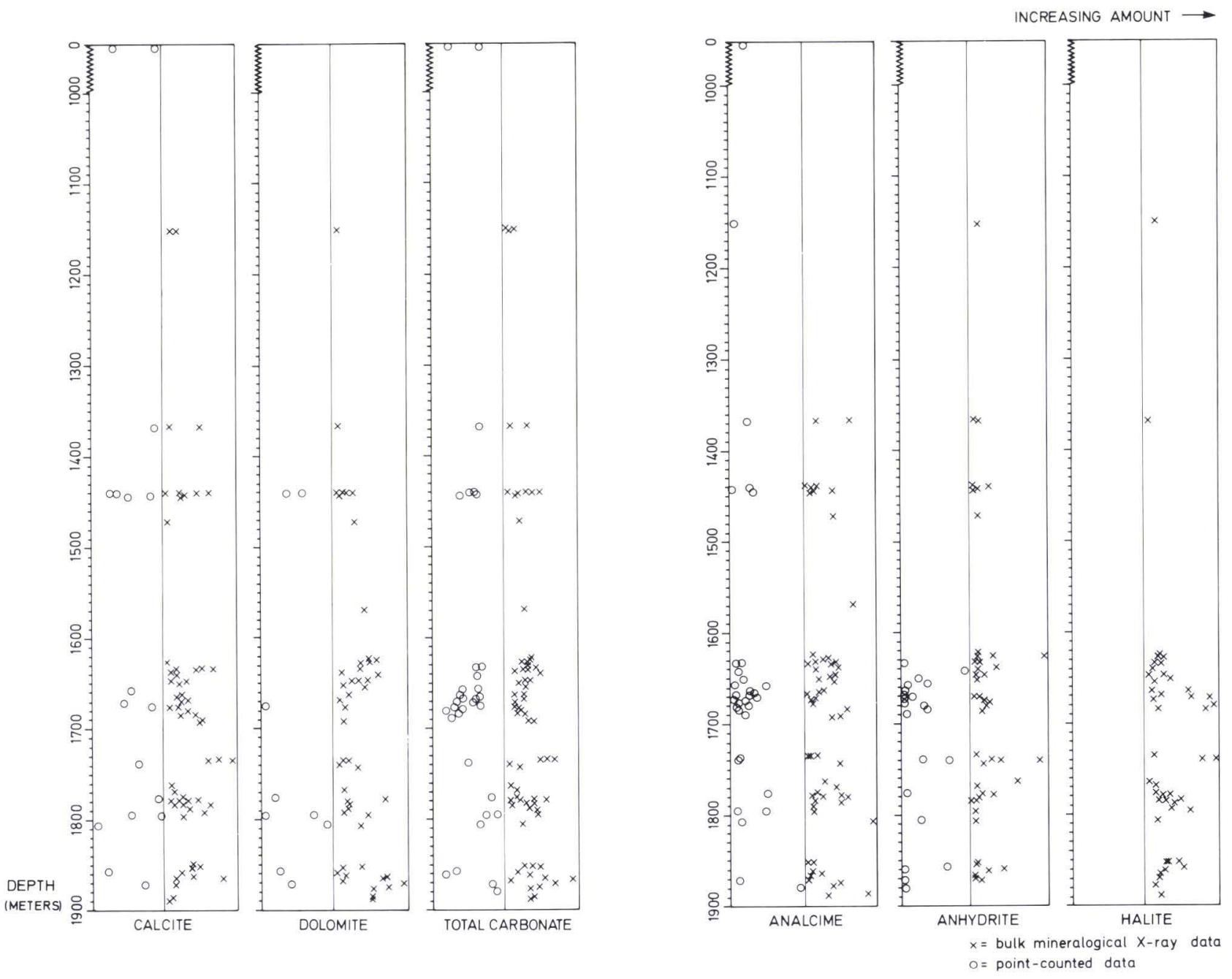

Fig. 12. Distribution of diagenetic minerals with increasing depth of burial in the Bunter Sandstone Formation. 
The clay assemblage does not appear to show any depth-related distribution. The ongoing replacement of detrital phases by mixed-layer clays however, indicates that the amount of diagenetic clay should increase with increasing burial depths. Shaw $(1980$, p. 65) indicated that smectites and vermiculites may transform to mixed-layer compositions in an alkaline environment but Foscolos \& Kodoma (1974) implied that smectite is first transformed to vermiculite during the illitization process. Both these clays appear to decrease in sandstones relative to mixed-layer types and with increasing burial, the mixed-layer clays will be transformed to il- lite or chlorite. According to Lahann (1980), the illitization reaction begins at around $50^{\circ} \mathrm{C}$, which is slightly lower than the bottom hole temperatures recorded today. Indeed, from the mixed-layer clays in figure 7 , it is probable that such a reaction has started. It is important to note however, that Singer and Stoffers (1979) showed that the smectite-illite transformation was not only depth-related (Hower et al. 1976), but could also occur at near-surface conditions in an arid, alkaline setting. These authors indicated that the local chemical environment, rather than high temperatures and pressures, could be the determining factor. 


\section{Diagenetic processes}

The study of diagenesis is underlain by a common theme; the interaction between mineral assemblages and the interstitial fluids. As succintly stated by Hayes (1979), diagenesis is a kinetic process, and the mineral assemblages reported here represent only the latest stage of an evolution in which various reactions have occurred in an ongoing attempt to reach equilibrium with a changing environment.

Comparisons of diagenesis in the Bunter Sandstone Formation with both recent (Walker 1967) and ancient (Fuchtbauer 1967, Burley 1984) analogs reveals that there is a remarkable similarity for sediments deposited in these arid and oxidizing environments. The differences that do occur can often be attributed to such local factors as depth of burial, provenance, structural setting and specific depositional subenvironment but these can be quite difficult to apply in more than a qualitative manner. Nevertheless, a unified diagenetic model can be generated, based upon the diagenetic sequence and the probable reactions that produced the observed changes.

Comparison with modern playa lakes (Last 1984) shows that the associated saline to hypersaline brines are dominated by sodium, magnesium and sulphate ions but there are also strongly variable amounts of chloride and bicarbonate ions. Much of the mineralogical character of these playas is attributed to chemical processes associated with either evaporitive concentration of the brines or groundwater discharge. The diagenetic system is thus programmed at a very early stage by its associated fluids and any further modifications may be expected to be directed by this initial control.

As an example, sodium-rich diagenetic minerals such as albite overgrowths and analcime are relatively common in the Bunter Sandstone Formation despite the absence of detrital phases which could be expected to yield significant amounts of sodium upon alteration (ie. acid volcanics). Nearly twenty years ago, Fuchtbauer (1967) observed that the distribution of secondary feldspars in the Buntsandstein could be related to a $\mathrm{Na} / \mathrm{K}$ line which was associated with the transition from a fluviatile environment with $\mathrm{K}$-feldspars to a brackish/saline environment where authigenic Na-feldspars were found. He stated that the depositional site was obviously the determining factor and also noted that the distribution of analcime closely paralleled that of albite. Later work suggests that the actual distribution of these phases may be more complex, but Fuchtbauer's major correlation with depositional environment appears to be equally valid today.

Changes may also be observed on a microscale. For example, microprobe analyses of albite overgrowths in the saline deposits of the Bunter Sandstone Formation show exceptional purity but associated K-feldspar overgrowths are considerably less pure than those reported for time-equivalent, fluviatially-dominated sequences in England (Ali \& Turner 1982) and in the Skagerrak Formation of northern Danmark (Andersen \& Nielsen, in prep.). In addition, no analcime has been reported from these fluviatile environments and albitic overgrowths are rare.

The generation of eogenetic calcite (e.g. calcrete) and gypsum cements can be related to calcium-enriched waters in the depositional environment. Several factors influence calcrete formation including the rate of deposition, groundwater movements, climate and the availability of calcium in the substratum (Nagtegaal 1969). Little can be said with certainty about these parameters but it seems likely that both the arid climate and the slow rate of deposition were favorable for calcrete formation. The fact that they are not observed more often therefore, could possibly be related to inadequate groundwater flushing resulting from effluent seepage and a fluctuating water table rather than an inadequate supply of calcium and sulphate ions.

The formation of dolomite is dependent upon the $\mathrm{Mg} / \mathrm{Ca}$ ratio (Katz 1970, Irwin 1980) as well as low concentrations of sulphate (Pierre et al. 1984). The first phase of dolomite formation, as rhombs in claystones, may have occurred as a direct response to early gypsum formation since this would both reduce the concentration of $\mathrm{SO}_{4}^{-2}$ and raise the $\mathrm{Mg} / \mathrm{Ca}$ ratio. Both events are limited to the same lithofacies and furthermore, they are found in Mg-rich clays.

Under the favorable $\mathrm{pH}$ and $\mathrm{Eh}$ conditions of the desert environment, iron will be rapidly oxidized to ferric oxide, and as a result of alteration to hematite with time, the sediments assume a bright red color. In fact, given the proper interstitial conditions, essentially all sediments contain enough iron to produce reddening (Walker \& Honea 1969). Titanium oxide minerals, such as anatase and rutile, might also be expected to form at this time.

The precipitation of feldspar and quartz overgrowths requires that sodium, potassium, aluminium and silicon 
are removed from the intrastratal fluids. Even through the amount of these cements is volumetrically insignificant in these sandstones, the solubilities of silicon and aluminium are so small under neutral to slightly alkaline conditions that the porewaters must constantly be renewed in order for precipitation (and dissolution) of aluminosilicates to proceed (Bjorlykke 1983). Although the mechanism of flushing can be discussed (Wood \& Hewett 1984, Land 1984), it would seem selfevident that by this time the sediments must have been buried below the water table and were continuously bathed in intrastratal fluids.

Intrastratal alteration of unstable silicates, both by clay replacement and dissolution, liberated a variety of cations into solution which could then be utilized in the generation of new authigenic phases. Mass balance studies would be needed to determine if dissolution and replacement alone could provide the material necessary for new phases, but as discussed above, the diagenetic system was already relatively enriched in $\mathrm{Na}^{+}$, $\mathrm{Ca}^{+2}$ and $\mathrm{Mg}^{+2}$ as a result of associated brines in the depositional environment. With continuing alteration of detrital and authigenic phases, these as well as other cations would be enriched in the associated fluids until such a time that precipitation of a specific phase resulted in a temporary reduction in the porewater concentrations of that (those) ions needed to form this new mineral.

The replacement of detrital grains to smectitic, vermiculitic and mixed-layer clays, requires the complex transfer of several cations and will particularly remove magnesium from solution. The large cation exchange capacities of these clays may buffer magnesium distribution and under sufficiently high $\mathrm{Si}$ and Na activities, conditions may be created for the simultaneous precipitation of dolomite and analcime. The common association of these minerals in claystones and heteroliths indicates that such conditions are best obtained in these lithofacies, possibly as a result of high magnesium contents.

Hutcheon (1981) showed that analcime could be formed directly from smectite given sufficiently high $\mathrm{Na}^{+} / \mathrm{H}^{+}$values and sufficiently low temperatures. Porewater analyses of the Bunter Sandstone Formation in the Tønder-5 well indicates that analcime is likely to be the stable phase here (fig. 13), and the common association of analcime with clay relicts suggests that such a reaction could have taken place. In addition, by using silica, aluminium and sodium to form analcime, the porewaters will become relatively enriched in calcium and magnesium ions released from smectite. This could

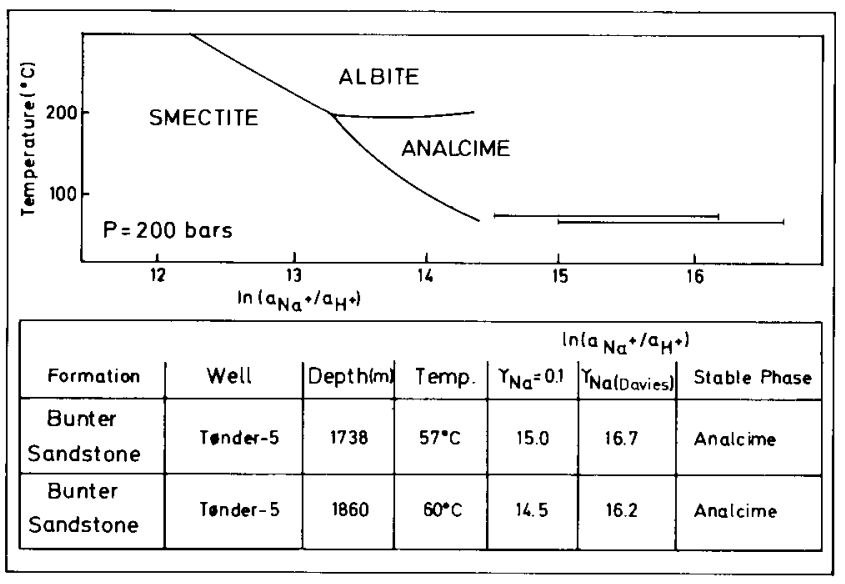

Fig. 13. Phase diagram, smectite-analcime-albite, after Hutcheon (198I). A geothermal gradient of $30^{\circ} \mathrm{C} / \mathrm{km}$ with a $6^{\circ} \mathrm{C}$ surface temperature was used and a constant $p H$ of 6.8 , based on an average of several measurements, was assumed. Concentrations of $\mathrm{Na}^{+}$were taken from porewater analyses (Troels Laier, pers.comm.), and two activity coefficients ( $\mathrm{Na}$ ) were used in order to illustrate a degree of spreading due to uncertain assumptions. The Davies equation is from Krauskopf $(1979$, p. 61). Note that analcime is the expected phase in all cases.

lead to the precipitation of dolomite, given adequate supplies of bicarbonate. Finally, the earlier observation that the $\mathrm{Si} / \mathrm{Al}$ ratio of analcimes is typical for those precipitated in saline, alkaline lakes suggests that the depositional brines still exerted a strong influence on subsequent porewater evolution.

The final cements, anhydrite and halite, are poikilotopic in texture and dominantly found in the sandstones where permeable pathways still existed. Due to the earlicr formation of several $\mathrm{Na}$ - and $\mathrm{Ca}$-rich phases (albite, analcime, gypsum, calcite, and dolomite), it is uncertain if these last two cements could also be generated in amounts greater than 20 vol. \% (table 2) from these modified brines. Migration from underlying Zechstein salts, in connection with halokinesis, is proposed as the source for these late cements. Although the data is inconclusive, it is interesting to note that these cements are only found in Rødby-1 and the Tønder wells, both of which lie on salt structures and within the Zechstein salt province. The absence of anhydrite and halite in Helgoland, where salt diapirism was also active, may possibly be attributed to later removal during telogenesis. Both Hancock (1978) and Dutton \& Land (1985) have related late stage anhydrite cements to migration from Permian evaporites and Fuchtbauer (1967) implied a Zechstein source for late stage halite in the Buntsandstein. 


\section{Conclusions}

The major factors controlling diagenesis in the Bunter Sandstone Formation are the saline brines associated with the depositional environment and, on a more local scale, the late-stage Zechstein fluids which migrated upwards as a result of salt diapirism in specific structural settings. Diagenetic pathways were established immediately upon deposition as a response to high concentrations of distinct ions in the enveloping brines. These pre-diagenetic controls were, in turn, modified by the subsequent alteration of the mineral assemblage which provided additional ions to the chemical system.

The diagenetic, facies-related variations documented in this report suggests that microenvironmental conditions were a controlling parameter which must be considered in any diagenetic model. As an example, the intimate association of analcime and dolomite, coupled with the greater abundances of these minerals in claystones and heteroliths, presumably reflects more favorable conditions of formation in the finer-grained lithofacies. It is also significant that these minerals are generally in association with claystone clasts or clayreplaced grains when found in sandstones. A smectiteanalcime reaction could explain these occurrences. Furthermore, early gypsum formation and adjustment of the $\mathrm{Ca} / \mathrm{Mg}$ ratio could explain the instances where dolomite rhombs are found in claystones but are not in association with (formed prior to) analcime. The distribution of eogenetic gypsum (now anhydrite) and dolomite together in claystone, and only in claystone, again strongly indicates a microenvironmental control on diagenesis.

Later stage dolomite and analcime can form from associated clays, and $\mathrm{Ca}^{+2}$ for calcite may have been provided by the original brines, dissolution of plagioclases, alteration of smectite and to a small extent, leaching of ooids. Quartz and feldspar overgrowths are volumetrically insignificant and the necessary cations could have been transferred from alteration of the associated detrital grains given sufficient porewater flushing. In contrast to the above eogenetic cements however, latestage anhydrite and halite require an outside source and Zechstein brines are invoked.

The formation of most of the authigenic phases documented in the Bunter Sandstone Formation obviously required an alkaline environment but the corrosion of feldspar, ooids and analcime, together with the occurrence of minor amounts of kaolinite, suggest that more acidic conditions were also active at times. Burley
(1984) discussed the possibilities of generating acidic porewaters, either by thermal decarboxylation of Permo-Triassic mudrocks or by migration from Carboniferous sediments, in an attempt to explain extensive mesogenetic carbonate dissolution in the Sherwood Sandstone. He favored the latter process and a similar event cannot be excluded for the Bunter Sandstone. However, large-scale mesogenetic formation of secondary porosity has not occurred here and significant ionic transfer by solutions moving over large transport distances may not be a necessary mechanism. Rather, a microenvironmental chemical model is suggested. If, for example, as shown by Hutcheon (1981), the reaction smectite-analcime releases hydrogen ions, then a lowered $\mathrm{pH}$ may be generated near the clay. As shown in plate $3 \mathrm{D}$, analcime is corroded within the original (smectite-replaced) grain boundary but not where it grew freely into porespace. In any case, subtle physiochemical conditions must have been active within the sediment since the degree of alteration can vary considerably over very short distances. Thus, even though microprobe analyses of analcime show a narrow range of chemical compositions, there may be a significant variation in their degree of alteration within even the limited area of a thin section. The same applies to other phases such as feldspars and ooids. In addition, there can also be major differences in alteration for grains which are in direct contact and might be expected to show similar chemical behavior (i.e. analcime and carbonate, plates $1 \mathrm{E}, 3 \mathrm{C}$ ). In a corresponding manner, Siebert et al. (1984) showed how calcite foraminifera were unaltered in a sand with strongly leached feldspars.

The overall diagenetic pattern in the Bunter Sandstone Formation (fig. 8) is typical of eogenetic alteration in redbed sequences (Walker 1967, Turner 1980, Burley 1984). The depositional environment is arid, alkaline and oxidizing and the diagenetic assemblage reflects these conditions. Position within the depositional basin is equally decisive since more saline to hypersaline brines may be expected towards the basin center. However, since geomorphology can create geochemical depocenters at any point in a basin (April 1980), trends based on lithofacies, rather than a simple basin edge to center model, may give a more accurate indication of expected diagenetic trends. The sediments in this study reflect a basinal, low-energy, evaporative, sodium-dominated assemblage. In contrast, prelimin- 
ary work shows that the time-equivalent Skagerrak Formation in northern Denmark is a more dynamic, higher-energy, fluviatile, potassium-rich diagenetic assemblage.

The potential role played by the detrital mineral assemblage must be measured in relation to the ions that these components can contribute vs. the ions which are available in the depositional brines. In other words, if the detrital assemblage mainly releases ions which are already abundant in the depositional brines, the diagenetic affects produced by dissolution may be masked relative to a situation where large quantities of different ions are introduced to the porewaters. Similarly, since the depositional fluids in the fluviatile Skagerrak Formation or Sherwood Sandstone (Burley 1984) are more dilute than the concentrated brines of the Bunter Sandstone Formation, the diagenetic effect exerted by dissolution of the detrital mineral assemblage may also be expected to be greater in the Skagerrak and Sherwood Sandstone Formations. It is significant that extensive amounts of anhydrite and halite are only reported in the Sherwood Sandstone in the Southern North Sea Basin (Burley 1985), as this area is closest to the Danish samples reported here and may most closely approximate the depositional environment of the Bunter Sandstone Formation.
The distribution of clay minerals in terms of lithologies related to specific environments within the depositional basin has been documented by April (1980). He described Late Triassic/Early Jurassic sediments associated with a floodplain-lacustrine system and showed that chemical controls and ionic concentrations changed from fluviatile redbeds to lacustrine gray and black shales. A geochemical blueprint was thus invoked at a very early stage for each lithology and related depositional system and this, it maybe assumed, strongly influenced the subsequent course of diagenesis.

The intensities of these events will, of course, be influenced by the specific microenvironments exerted within the individual lithofacies. As the abundance and distribution of these facies in the total stratigraphic profile is a unique reflection of the depositional setting, local variations in diagenesis must be expected. Where concentrated brines are present however, a strong initial and unifying influence is exerted, but in more dilute porewaters, a more variable diagenetic history may by found. Later changes, associated with increasing depth of burial may be predictable, yet they are a response which demands knowledge of earlier diagenetic controls. 


\section{Summary}

1. A well-preserved diagenetic assemblage has been described in the Lower Triassic Bunter Sandstone Formation, onshore Denmark.

2. The eogenetic assemblage consists of quartz and feldspar overgrowths, Fe-Ti oxides, iron-poor calcite and dolomite, analcime, gypsum and clays and is indicative of highly evaporative conditions in the depositional basin. Mesogenetic anhydrite and halite, on the other hand, are associated with Zechstein brines from underlying salt structures.

3. The distribution af diagenetic minerals is clearly related to lithofacies. Thus, analcime and dolomite are most abundant in claystones and heteroliths whereas halite, anhydrite and mixed-layer clays are most common in sandstones. Variations in the primary mineralogy, the access of permeable pathways and the type of depositional brine associated with each facies can all, to some extent, explain the facies related variations observed in the diagenetic assemblage.

4. An overriding diagenetic parameter however, is the influence of the depositional brine and the relative position of the sedimentary pile within the depositional basin. Where the depositional brines are concentrated (saline to hypersaline), they will strongly influence the direction of eogenesis and mask the effects caused by other sources of ionic input such as grain dissolution.

5. In the Bunter Sandstone Formation, the depositional brines were probably sodium-rich. This is reflected both in the abundance of analcime and the purity of albite overgrowths. However, variations within each facies, together with documented mineralogical associations (ie. dolomite-analcime, gypsum-dolomite), suggests that microenvironmental reactions directed the specific diagenetic pathways. As such, any later large-scale, depth-related changes are a response to these early eogenetic imprints.
Acknowledgements

This report summarizes part of an Energy Research Project funded by the Danish Ministry of Energy. Numerous people and institutions helped during this work and I want to specifically thank the following:

Geological Survey of Denmark (DGU) Palle Rubæk Andersen, Gert Grønning, Flemming Larsen, Carsten Hansen, Carsten Boesen, Kirsten Friis, Henrik Pedersen, Eva Melskens, Gitte Nicolaisen, Jens Peder Høj, Pia Andersen and Dorthe Plougmann.

Dansk Olie og Naturgas A/S (D.O.N.G.) Bjarne Leth Nielsen, Viggo Jensen, Christian Knudsen. D.O.N.G. is also thanked for providing several internal reports.

\section{University of Arhus Henrik Friis.}

University of Copenhagen Jørn Rønsbo and John Fløng for use of the electron microprobe and Hans Jørgen Hansen and Jørgen Fuglsang for use of the SEM.

Stuart Burley (Universität Bern), Peter Turner (University of Aston in Birmingham), Bjarne Leth Nielsen (D.O.N.G.) and Palle Rubæk Andersen (DGU) read the manuscript and offered valuable advice. 
Ali, A.D. \& Turner, P., 1982: Authigenic K-Feldspar in the Bromsgrove Sandstone Formation (Triassic) of Central England. - Jour. Sed. Pet., 52 (1), pp. 187-197.

Andersen, P.R. \& Nielsen, B.L., 1986: Diagenesis of the Skagerrak Formation, Denmark.

April, R.H., 1981: Clay petrology of the Upper Triassic/Lower Jurassic terrestrial strata of the Newark Supergroup, Connecticut Valley, U.S.A. - Sed. Geol., 29 (4), pp. 283-307.

Audley-Charles, M.G., 1970: Triassic paleogeography of the British Isles. - Q.J. Geol. Soc. 126, pp. 50-81.

Berner, R.A. \& Holdren, Jr. G.A., 1977: Mechanisms of feldspar weathering: Some observational evidence. - Geology, 5, pp. 369372 .

Bertelsen, F., 1980: Lithostratigraphy and depositional history of the Danish Triassic. - Danm. geol. Unders., Ser B., 4, 59 pp.

Bjørlykke, K., 1983: Diagenetic reactions in sandstones. - In: Parker, A. \& Sellwood, B.W., pp. 169-213.

Boles, J.R., 1978: Active Ankerite Cementation in the Subsurface Eocene of Southwest Texas. - Contrib. Mineral. Petrol., 68, pp. $13-22$.

Boles, J.R. \& Franks, S.G., 1979: Clay Diagenesis in Wilcox Sandstones of Southwest Texas: Implications of Smectite Diagenesis on Sandstone Cementation. - Jour. Sed. Pet., 49(1), pp. 55-70.

Burley, S.D., 1984: Patterns of diagenesis in the Sherwood Sandstone Group (Triassic), United Kingdom. - Clay Minerals, 19, pp. $403-440$.

Burley, S.D., 1985: Diagenetic Modelling in the Triassic Sherwood Sandstone Group of England and its Offshore Equivilents, United Kingdom Continental Shelf. - Thesis, University of Hull. England

Burley, S.D. \& Kantorowicz, J.D., 1986: Thin Section and S.E.M Textural Criteria for the Recognition of Cement-Dissolution Porosity in Sandstones. - Sedimentology 33, pp. 587-604.

Burley, S.D., Kantorowicz, J.D., \& Waugh, B., 1985: Clastic Diagenesis. - In: Sedimentology - Recent developments and applied aspects (Brenchley, P. T. \& Williams, B.P.J. (eds.)), pp. 189-226.

Carroll, D., 1970: Clay Minerals: A Guide to their X-ray Identification. - Geol. Soc. Am. Spec. Pap. 126, 80 pp.

Chilingarian, G.V. \& Wolf, K.H., 1976: Compaction of CoarseGrained Sediments 2. - Developments in Sedimentology, 18B, Elsevier, 808 pp.

Clark, D.N. \& Tallbacka, L., 1980: The Zechstein deposits of southern Denmark. - Contr. Sedimentology 9, pp. 205-231.

Clemmensen, L.B., 1979: Triassic lacustrine red-beds and paleoclimate: The "Buntsandstein" of Helgoland and the Malmros Klint Member of East Greenland. - Geologisches Rundschau, 68 (2), pp. 748-774.

Clemmensen, L.B., 1986: Desert sand plain and Sabkha deposits from the Bunter Sandstone Formation (L. Triassic) at the northern margin of the German Basin . - Geologisches Rundshau, 74 (3), pp. $519-536$.

Colter, V.S. \& Ebbern, J., 1978: The petrography and reservoir properties of some Triassic sandstone of the Northern Irish Sea Bassin. - Jl. Geol. Soc. Lond., 135, pp. 57-62.

Dunoyer de Segonzac, G., 1970: The Transformation of Clay Minerals during Diagenesis and Low-Grade Metamorphism: A Review. - Sedimentology, 15 (3/4), pp. 2 81-346

Dutton, S.P. \& Land, L., 1985: Meteoric Burial Diagenesis of Pennsylvanian Arkosic Sandstones, Southwestern Anadarko Basin, Texas. - AAPG Bull., 69 (1), pp. 22-38.

Fine, S., 1985: Documentation for computer programmel and pointcounting procedure developed for the diagenesis project. - Danm. geol. Unders., Int. rep. 28, 50 pp.
Fine, S., 1986: Revision of Triassic lithostratigraphy, Denmark. Danm. geol. Unders., Ser. C. in press.

Folk, R.L., 1968: Petrology of Sedimentary Rocks. - Austin, Texas., Hemphills Book Store, $170 \mathrm{pp}$.

Foscolos, A.E \& Kodama, H., 1974: Diagenesis of Clay Minerals from Lower Cretaceous Shales of North Eastern British Columba - Clays and Clay Minerals, 22, pp. 319-355.

Friedman, G., 1971: Staining. - In: Procedures in Sedimentary Pe trology (Carver, R.E. ed.), Wiley, Interscience, pp. 511-530.

Fuchtbauer, H., 1967: Influence of Depositional Enviroment on Diagenesis of the Triassic Bunter Sandstone. - Sedimentary Geology, 1 , pp. 159-179.

Fuchtbauer, H., 1979: Die Sandsteindiagenese im Spiegel der neueren Literatur. - Geologisches. Rundschau, 68 (3), pp. 1125-1151.

Fuchtbauer, H., 1983: Facies Controls on Sandstone Diagenesis. In: Parker, A. \& Sellwood, B.W., pp. 269-288.

Glennie, K.W., Mudd, G.C. \& Nagtegaal, P.J.C., 1978: Depositional environment and diagenesis of Permian Rotliegendes Sandstones in Leman Bank and Sole Pit areas of the U.K., southern North Sea. - Jl. geol. Lond., 135, pp. 25-34

Hancock, N.J., 1978: Possible causes of Rotliegend sandstone diagenesis in northern West Germany. - Jl. geol. Soc. Lond. 135, pp. $35-40$.

Hay, R. L., 1966: Zeolites and Zeolitic Reactions in Sedimentary Rocks. - Geol. Soc. Am. Spec. Pap. 85, 128 pp.

Hayes, J., 1979: Sandstone Diagenesis - The Hole Truth. - SEPM Spec. Pub. 26, pp. 127-139.

Heald, M.T. \& Baker, G.F., 1977: Diagenesis of the Mt. Simon and Rose Run Sandstones in western West Virgina and southern Ohio. - J. Sed. Pet., 47 (1), pp . 66- 77.

Helmold, K.P. \& van de Kamp, P.C., 1984: Diagenetic Mineralogy and Controls on Albitization and Laumontite Formation in Paleogene Arkoses, Santa Ynez Mountains, California. - In: McDonald, D.A. \& Surdam, R.C. (eds.), pp. 239-277.

Hower, J., Eslinger, E.V., Hower, M.E. \& Perry, E.A., 1976: Mechanism of burial metamorphism of argillaceous sediment: 1 . Mineralogical and chemical evidence. - Geol. Soc. Am. Bull., 87, pp. $725-737$

Hutcheon, I., 1981: Applications of Thermodynamics to Clay Minerals and Authigenic Mineral Equilibria. - In: Clays and the Resource Geologist (Longstaffe , F.J. -ed.), Short Course Handbook, 7, Mineralogical Association of Canada, pp. 169-193.

Irwin, H., 1980: Early diagenetic carbonate precipitation and porefluid migration in the Kimmeridge Clay of Dorset, England. Sedimentology, 27, pp. 577- 591.

Ixer, R.A., Turner, P. \& Waugh, B., 1979: Authigenic iron and titanium oxides in Triassic redbeds: (St. Bees Sandstone), Cumbria, Northern England. - Geol. J ., 14 (2), pp. 179-192.

Jeans, C.V., 1978: The origin of the Triassic clay assemblages of Europa with special reference to the Keuper Marl and Rhaetic of parts of England. - Phil. Trans. Roy. Soc. Lond., Ser. A, 289 (1365), pp. 549-639.

Katz, A., 1971: Zoned Dolomite Crystals. - Jour. Geol., 79, pp. 38-51.

Kessler, L.G., 1978: Diagenetic sequence in ancient sandstones deposited under desert climatic conditions. - Jl. geol. Soc. Lond., 135, pp. 41-49.

Knox, W.B.O'B., Burgess, W.G., Wilson, K.S. \& Bath, A.H., 1984 : Diagenetic Influences on Reservoir Properties of the Sherwood Sandstone (Triassic) in the Marchwood Geothermal Borehole, Southampton, U.K. - Clay Minerals, 19, pp. 441-456. 
Krauskopf, K.B., 1979: Introduction to Geochemistry. - McGraw Hill Book Company, 617 pp.

Lahann, R.W., 1980: Smectite Diagenesis and Sandstone Cement: The Effect of Reaction Temperature. - Jour. Sed. Pet., 50 (3), pp. 755-760.

Land, L.S., 1984: Frio Sandstone Diagenesis, Texas Gulf Coast: A Regional Isotopic Study. - In: McDonald, D.A. \& Surdam, R.C. (eds.), pp. 47-63.

Larsen, G. \& Friis, H., 1975: Triassic heavy-mineral association in Denmark. - D.G.U. Årbog 1974, pp. 33-47.

Last, W.M., 1984: Sedimentology of playa lakes of the northern Great Plains. - Can. J. Earth Sci., 21, pp. 107-125.

Loucks, R.G., Richmann, D.L. \& Milliken, K.L., 1981: Factors Controlling Reservoir Quality in Tertiary Sandstones and their Sig nificance to Geopressured Geothermal Production. - Report of Investigations No. 111. Bureau of Economic Geology, The University of Texas at Austin, $41 \mathrm{pp}$.

Mader, D., 1981: Diagenesis of the Buntsandstein (Lower Triassic) in Western Eifel (Germany). - N. Jb. Miner. Abh., 142 (1), pp. 1-26.

Mader, D., 1982: Aeolian Sands in continental redbeds of the Middle Buntsand-stein (Lower Triassic) at the western margin of the German Basin. - Sed. Geol., 31, pp. 191-230.

Mader, D., 1983: Evolution of fluvial sedimentation in the Buntsandstein (Lower Triassic) of the Eifel (Germany). - Sed. Geol., 37, $1 / 2$, pp. $1-84$

Markert, J.C. \& Al-Shaieb, Z., 1984: Diagenesis and Evolution of Secondary Porosity in Upper Minnelusa Sandstones, Powder River Basin, Wyoming. - In: McDonald, D.A. \& Surdam, R.C. (eds.), pp. 367-391.

McDonald, D.A. \& Surdam, R.C. (eds.), 1984: Clastic Diagenesis.AAPG Mem. 37, 434 pp.

McHargue, T.R. \& Price, R.C., 1982: Dolomite from clay in argillaceous or shale-associated marine carbonates. - Jour. Sed. Pet. 52 (3), pp. 873-886.

Michelsen, O., (ed.), 1981: Kortlægning af potentielle geotermiske reservoirer i Danmark. - Danm. geol. Unders., Ser. B, Nr. 5, 96 pp.

Morad, S., 1983: Diagenesis and Geochemistry of the Visingsø Group (Upper Proterozoic), Southern Sweden: A Clue to the Origin of Color Differentation. - Jour. Sed. Pet., 53 (1), pp. 51-65.

Murray, R.C., 1964: Origin and Diagenesis of Gypsum and Anhydrite. - Jour. Sed. Pet., 34 (3), pp. 512-523.

Nagtegaal, P.J.C., 1969: Microtextures in Recent and Fossil Caliche. - Leidse Geologische Mededelingen, 42, pp. 131-142.

Nagtegaal, P.J.C., 1978: Sandstone-framework instability as a function of burial diagenesis. - Jl. geol. Soc. Lond., 135, pp. 101-105.

Ortiz, L.R. \& Orti Cabo, F., 1980: Presencia de analcima y observaciones dia-geneticas en la anhidrita basal de la cuenca potasica de Navarra (Eoceno superior, cuenca del Ebro, Espana). - Revista del Instituto de Investigacion es Geologicas, Diputacion Provincial, Universidad de Barcelona, 34, pp. 223-235.

Parker, A. \& Sellwood, B.W.(eds.), 1983: Sediment Diagenesis. NATO ASI series. Series C, Matematical and physical sciences, $115,427 \mathrm{pp}$.

Pierre, C., Ortlieb, L. \& Person, A., 1984: Supratidal Evaporitic Dolomite at Ojo de Liebre Lagoon: Mineralogical and Isotopic Arguments for Primary Crystallization. - Jour. Sed. Pet., 54 (4), pp. 1049-1061.
Pittman, E.D., 1972: Diagenesis of Quartz in Sandstones as Revealed by Scanning Electron Microscopy. - Jour. Sed. Pet., 42 (3), pp. 507-519.

Rhys, G.H., 1974: A proposed standard lithostratigraphic nomenclature for the southern North Sea and an outline structural nomenclature for the whole of the (UK) North Sea. - Inst. geol. Sc. Report 74/8, 14 pp.

Sabins, F.F.Jr., 1962: Grains of Detrital, Secondary, and Primary Dolomite from Cretaceous Strata of the Western Interior. - Geol. Soc. Am. Bull., 73, pp. 1183-1196.

Schmidt, V. \& McDonald, D.A., 1979: The Role of Secondary Porosity in the Course of Sandstone Diagenesis. - SEPM Spec. Pub. 26, pp. 175-207

Shaw, H.F., 1980: Clay Minerals in Sediments and Sedimentary Rocks. - Developments in Petroleum Geology, G.D. Hobson (ed.), 2, pp. 53-85.

Siebert, R.M., Moncure, G.K. \& Lahann, R.W., 1984: A Theory of Framework Grain Dissolution in Sandstones. - In: McDonald, D.A. \& Surdam, R.C. (eds.), pp. 163-177

Singer, A. \& Stoffers, P., 1980: Clay Mineral Diagenesis in Two East African Lake Sediments. - Clay Minerals, 15 (3), pp. 291-307.

Simone, L., 1981: Ooids: A Review. - Earth Science Reviews, 16, pp. 319-355

Turner, P., 1980: Continental Red Beds. - Developments in Sedimentology 29, Elsevier, 562 pp.

Van Houten, F.B., 1962: Cyclic Sedimentation and the Origin of Analcime-Rich Upper Triassic Lockatong Formation, West Upper Central New Jersey and Adjacent Pennsylvania. - Am. Jour. Sci., $260(8)$, pp. 561-576.

Walker, T.R., 1967: Formation of Red Beds in Modern and Ancient Deserts. - Geol. Soc. Am. Bull., 78, pp. 353-368.

Walker, T.R., 1976: Diagenetic Origin of Continental Red Beds. The Continental Permian in Central, West and South Europe, H. Falke (ed.), pp. 240-282.

Walker, T.R. \& Honea, R.M., 1969: Iron Content of Modern Deposits in the Sono- ran Desert: A Contribution to the Origin of Red Beds. - Geol. Soc. Am. Bull., 80, pp. 535-544.

Walker, T.R., Waugh, B. \& Crone, A.J., 1978: Diagenesis in firstcycle desert alluvium of Cenozoic age, southwestern United States and northwestern Mexico. - Geol. Soc. Am. Bull., 89, pp. 19-32.

Waugh, B., 1970: Formation of quartz overgrowths in the Penrith Sandstone (Lower Permian) of northwest England as revealed by scanning electron microscopy. - Sedimentology 14, pp. 309-320.

Waugh, B., 1978: Authigenic K-Feldspars in British Permo-Triassic sandstones. - Jl. geol. Soc. Lond., 135, pp. 51-56.

Whetten, J.E., 1984: SEM Petrology Atlas. - AAPG Metods in Explorations Series, 4, $237 \mathrm{pp}$.

Wilkinson, J.F.G. \& Whetten, J.T., 1964: Some Analcime-Bearing Pyroclastic and Sedimentary Rocks from New South Wales. - Jour. Sed. Pet., 34(3), pp. 543-553.

Wilson, M.D. \& Pittman, E.D., 1977: Authigenic Clays in Sandstones: Recognition and Influence on Reservoir Properties and Paleoenvironmental Analysis. - Jour. Sed. Pet., 47 (1), pp. 3-31.

Wood, J.R. \& Hewett, T.A., 1984: Reservoir Diagenesis and Convective Fluid Flow. - In: McDonald, D.A. \& Surdam, R.C. (eds.), pp. 99-110.

Zimmerle, W., 1982: Authigenic Growth of Whisker-Like Fibrous Sericite Into Detrital Quartz. - Estudios geol., 38, pp. 361-365. 
PLATES 1-5 
PLATE 1.

A. Rounded quartz overgrowths (qo) suggesting that this quartz grain (g) may be a recycled sedimentary fragment. Tønder-4, 1976.50 m, two polarizers. Bar $100 \mu \mathrm{m}$.

B. Clay (cl) replacement of K-feldspar (Kfs, stained yellow) showing structural control. Clay is strongly hematite-stained. Tønder-3, 1651.03 m, two polarizers. Bar $25 \mu \mathrm{m}$.

C. Strong intragranular dissolution of plagioclase (plfs). Note how grain morphology is generally preserved, indicating that dissolution postdated most compaction. Tonder-3, $1651.03 \mathrm{~m}$, one polarizer. Bar $50 \mu \mathrm{m}$.

D. Deformed muscovite $(\mathrm{mu})$. The grain which penetrated the mica is now removed (arrow), indicating that dissolution followed compaction. Tonder-3, $1663.94 \mathrm{~m}$, one polarizer. Bar $100 \mu \mathrm{m}$.

E. Ooid showing small drusy calcite crystals (c) growing radially from margins. A euhedral, pore-filling and partially leached analcime (an) is also seen on the ooid margin. Textural relationships indicate that analcime preceded calcite growth, but the absence of drusy calcite within the leached analcime suggests that dissolution post-dated calcite. Pressure solution (ps) caused by quartz penetration of the ooid is also observed. Note the thick iron oxide crust at this solution boundary. Tønder-3, $1671.30 \mathrm{~m}$, one polarizer. Bar $100 \mu \mathrm{m}$.

F. Thick calcite growth (stained red) from darker colored ooid cores resulting in extensive cement (ce), Note the partial dissolution in some ooid interiors (diss). Tønder-4, $1795.42 \mathrm{~m}$, one polarizer. Bar $600 \mu \mathrm{m}$.

G. Dolomite-replaced claystone clast. Note beginning dissolution (diss). Tønder-5, $1857.35 \mathrm{~m}$, one polarizer. Bar $100 \mu \mathrm{m}$.

H. Replacement dolomite rhomb poikilotopically cementing surrounding grain. Note the rounded, dolomitized clay-filled core (co). These are nearly always seen inside these replacement dolomites and perhaps were $\mathrm{Mg}$-rich pellets. Microprobe analyses of core and rim show no compositional differences. Tønder-3, $1806.05 \mathrm{~m}$, one polarizer. Bar $100 \mu \mathrm{m}$. 

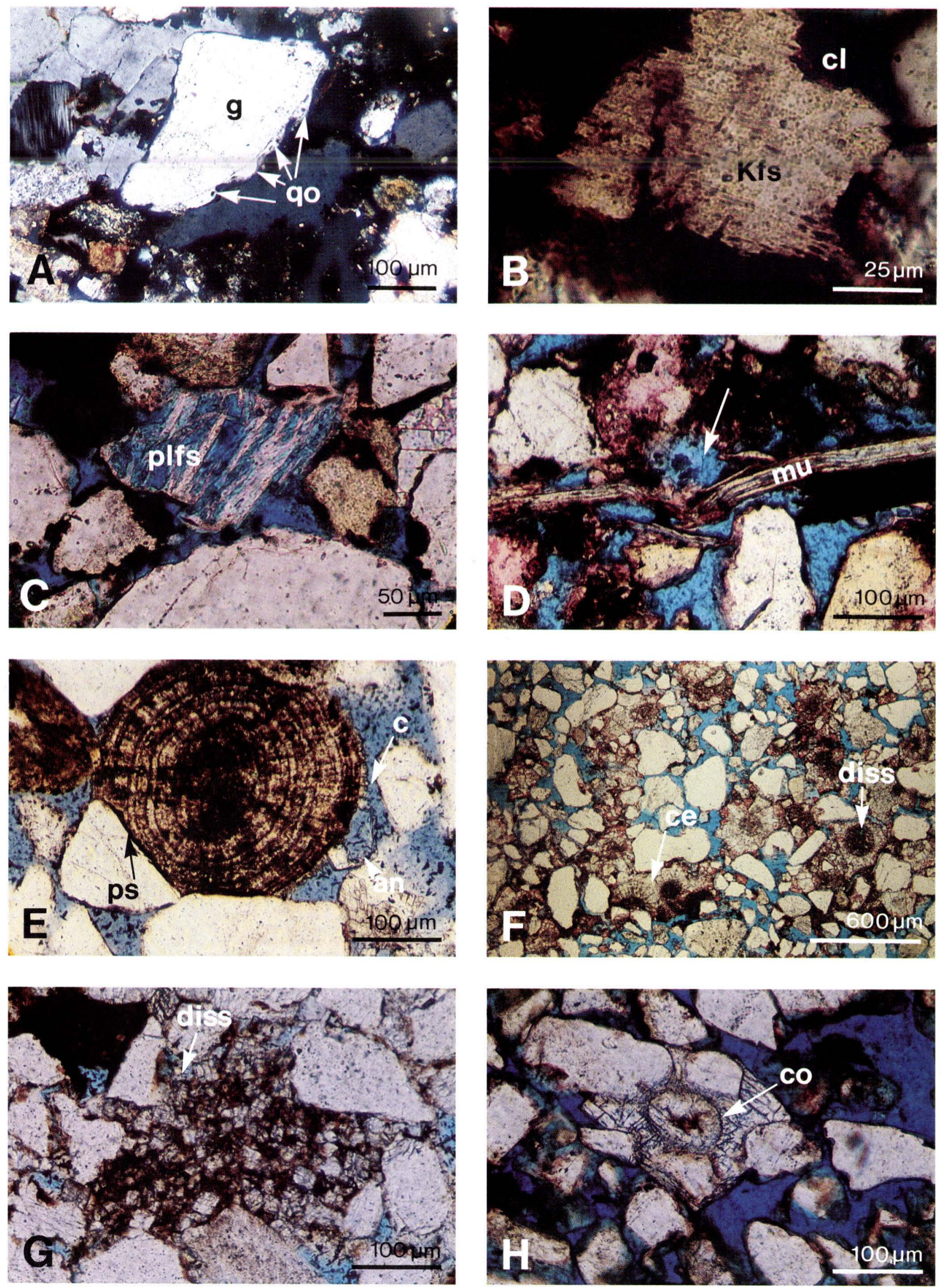
PLATE 2.

A. Mechanically induced impact pits (im) on detrital quartz grain (g). Preservation of these features suggests limited post-depositional chemical etching. Tønder-3, $1663.94 \mathrm{~m}$. Bar $10 \mu \mathrm{m}$.

B. Structurally controlled dissolution of K-feldspar ( $\mathrm{fs}$ ) on (010). Unaltered facet is not overgrowth, but simply a more resistant crystal surface (110). Arnu-1, $1440.48 \mathrm{~m}$. Bar $10 \mu \mathrm{m}$.

C. Dissolution and clay replacement (cl) of feldspar (fs). Tønder-3, $1655.35 \mathrm{~m}$. Bar $10 \mu \mathrm{m}$.

D. Pore-filling drusy growth of calcite (c) extending radially from ooid (oo) margins. Arnum-1, $1442.98 \mathrm{~m}$. Bar $30 \mu \mathrm{m}$.

E. Pressure-solution (ps) resulting from soft ooid (oo) being deformed by harder quartz grain (q). Tønder-5, $1868.66 \mathrm{~m}$. Bar $100 \mu \mathrm{m}$.

F. Clay clast with many dolomitic rhombs (do). The peripheral position of several rhombs $(1,2)$ within the clasts suggests formation after transport and deposition. Tønder-3, $1651.03 \mathrm{~m}$. Bar $10 \mu \mathrm{m}$.

G. Quartz overgrowths (qo) on clay-lined surface (cls) of quartz grain. Tønder-3, $1651.03 \mathrm{~m}$. Bar $10 \mu \mathrm{m}$.

H. Bladelike feldspar overgrowths (fo) on plagioclase. EDS indicates overgrowths are albitic. Tønder-3, $1795.00 \mathrm{~m}$. Bar $10 \mu \mathrm{m}$. 

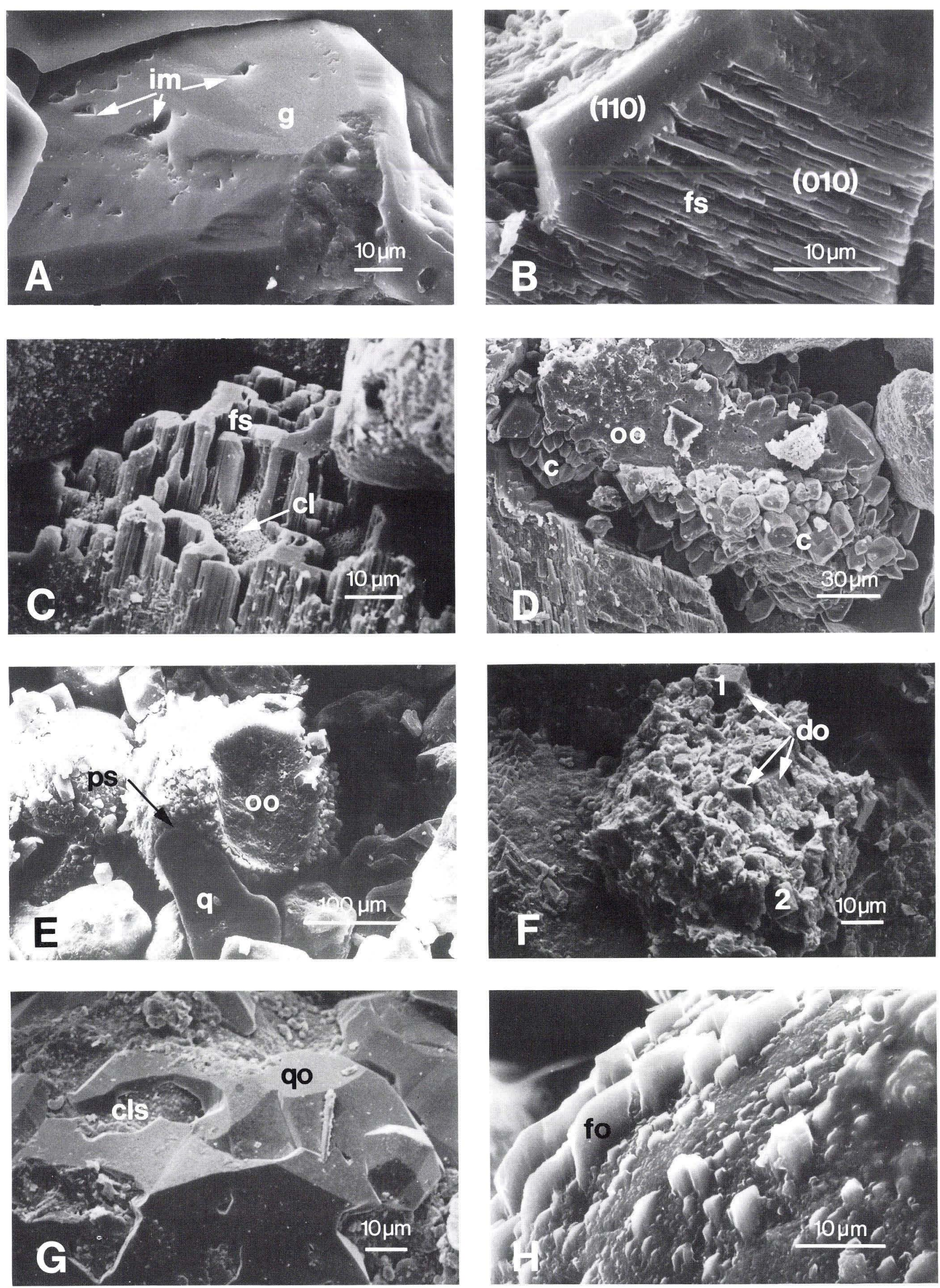


\section{PLATE 3.}

A. Feldspar overgrowths (fo) with hacksaw terminations. EDS indicates that they are K-feldspar. Tønder-3, 1795.00 m. Bar $5 \mu \mathrm{m}$.

B. Association of dolomite (do) and analcime (an) as pore-filling phases. Tønder-3, $1806.05 \mathrm{~m}$. Bar $30 \mu \mathrm{m}$.

C. Intimate intergrowth of pore-filling dolomite (do) and analcime (an). Note the fresh nature of the dolomite but the corroded character of the analcime, especially the crystal in the upper left (arrow). Tønder-3, $1806.05 \mathrm{~m}$. Bar $10 \mu \mathrm{m}$.

D. Analcime (an) with clay lining (cl). Note how the crystal inside the clay lining is strongly corroded (co) whereas analcime to the outside is euhedral and fresh. The corroded analcime may represent the product of clay replacement whereas the unaltered analcime may represent additional pore-filling growth. Tønder-3, $1651.03 \mathrm{~m}$. Bar $5 \mu \mathrm{m}$.

E. Poikilotopic, pore-filling anhydrite cement (anhy). Note the dramatic effect on porosity. Tønder-3, $1654.80 \mathrm{~m}$. Bar $20 \mu \mathrm{m}$.

F. Pore-filling barite (ba) as determined by EDS. Arnum-1, $1444.18 \mathrm{~m}$. Bar $30 \mu \mathrm{m}$.

G. Tangentially-oriented platelets of infiltrated clay on detrital grain surface. Tønder-3, $1657.00 \mathrm{~m}$. Bar $2 \mu \mathrm{m}$.

H. Clay linings forming pore-bridging meniscus (pbm). EDS suggests that such infiltrated clay is illitic. Tønder-3. $1795.00 \mathrm{~m}$. Bar $5 \mu \mathrm{m}$. 

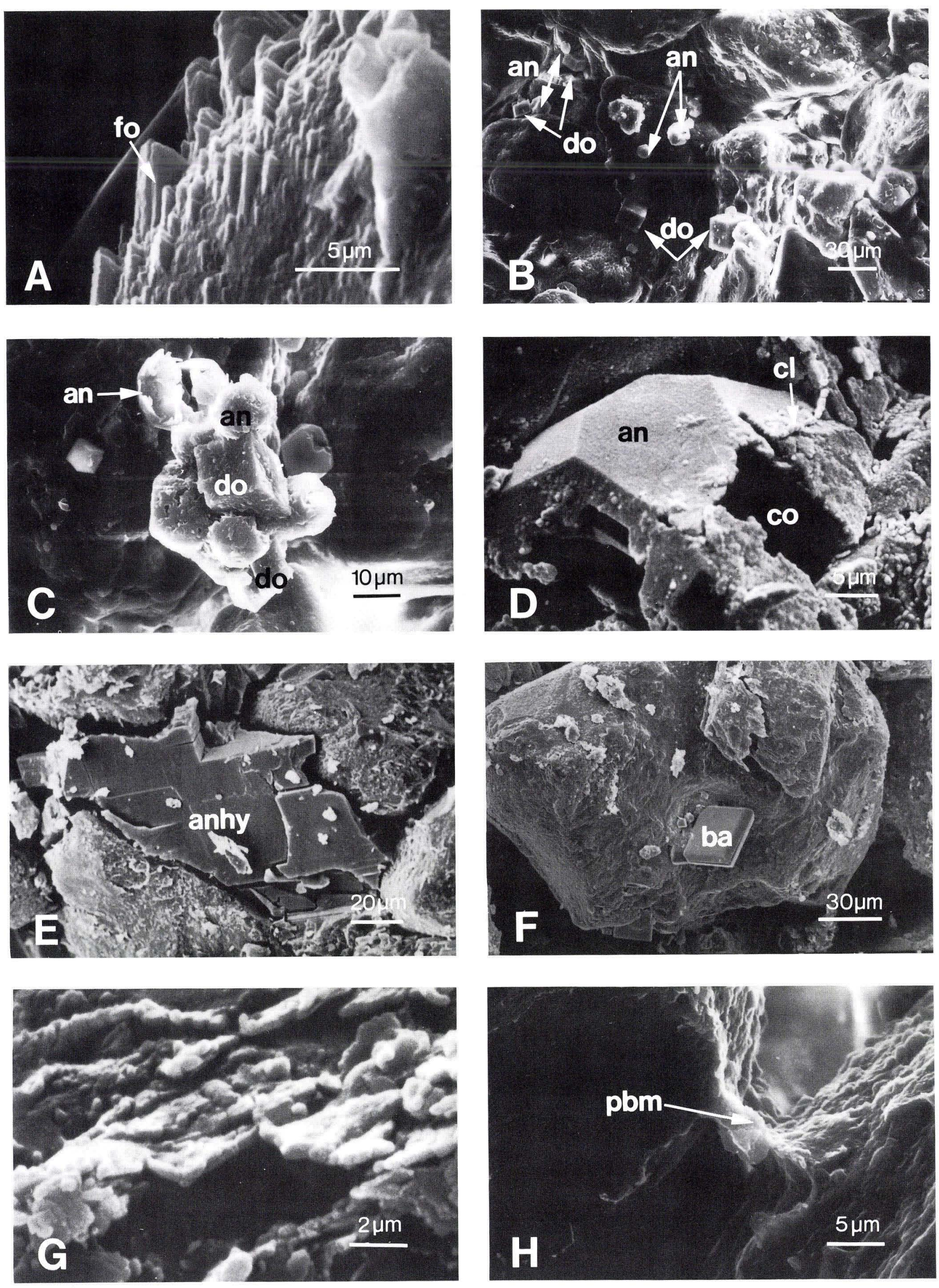
PLATE 4.

A. Analcime (an) filling oversized pore (dashed). Packing relationships clearly indicate that grain was removed and relicts within the analcime suggest a former smectitic? clay (cl). A detrital grain may have been replaced by clay which was itself replaced by analcime. Note that the analcime is partially dissolved. Tønder-4, $1666.05 \mathrm{~m}$, one polarizer. Bar $100 \mu \mathrm{m}$.

B. Dolomitic claystone with analcime (an) infilling vugs and dolomite (do) crystals lining vugs. Tønder-4, $1768.40 \mathrm{~m}$, one polarizer. Bar $200 \mu \mathrm{m}$. C. Ooid (oo-stained red), being replaced by anhydrite cement (anhy). Note the interpenetrants (arrow) and the ooid margin (mar). Authigenic, drusy calcite crystals are not seen. Tønder-5, $1868.73 \mathrm{~m}$, two polarizers. Bar $50 \mu \mathrm{m}$.

D. Analcime (an) being replaced by anhydrite (anhy). The irregular dissolution of the analcime suggests that it was leached prior to anhydrite cementation. Tønder-5, $1739.59 \mathrm{~m}$, two polarizers. Bar $25 \mu \mathrm{m}$.

E. Hematite-stained, pore-lining infiltrations clay (ic) forming a pore-bridging meniscus(pbm). Rødby-1, $1151.72 \mathrm{~m}$, one polarizer. Bar $50 \mu \mathrm{m}$.

F. Calcrete. Note the floating grains caused by displacive calcite cementation and note the absence of clay linings and leaching in the detrital grains. Calcite is stained red, K-feldspars are yellow. Rødby-1, $1152.14 \mathrm{~m}$, one polarizer. Bar $1000 \mu \mathrm{m}$.

G. Probable basal cut (001) (dashed), of a clay-replaced amphibole (am) now undergoing intragranular dissolution. Hønning-1, 1633.60 m, one polarizer. Bar $100 \mu \mathrm{m}$.

H. Late stage quartz overgrowths (qo) following analcime (an). The analcime probably replaces clay (see higher birefrigent relicts (r) in analcime). Tønder-3, $1677.24 \mathrm{~m}$, two polarizers, with gyps $\mu$ plate to enhance contrast. Bar $25 \mu \mathrm{m}$. 

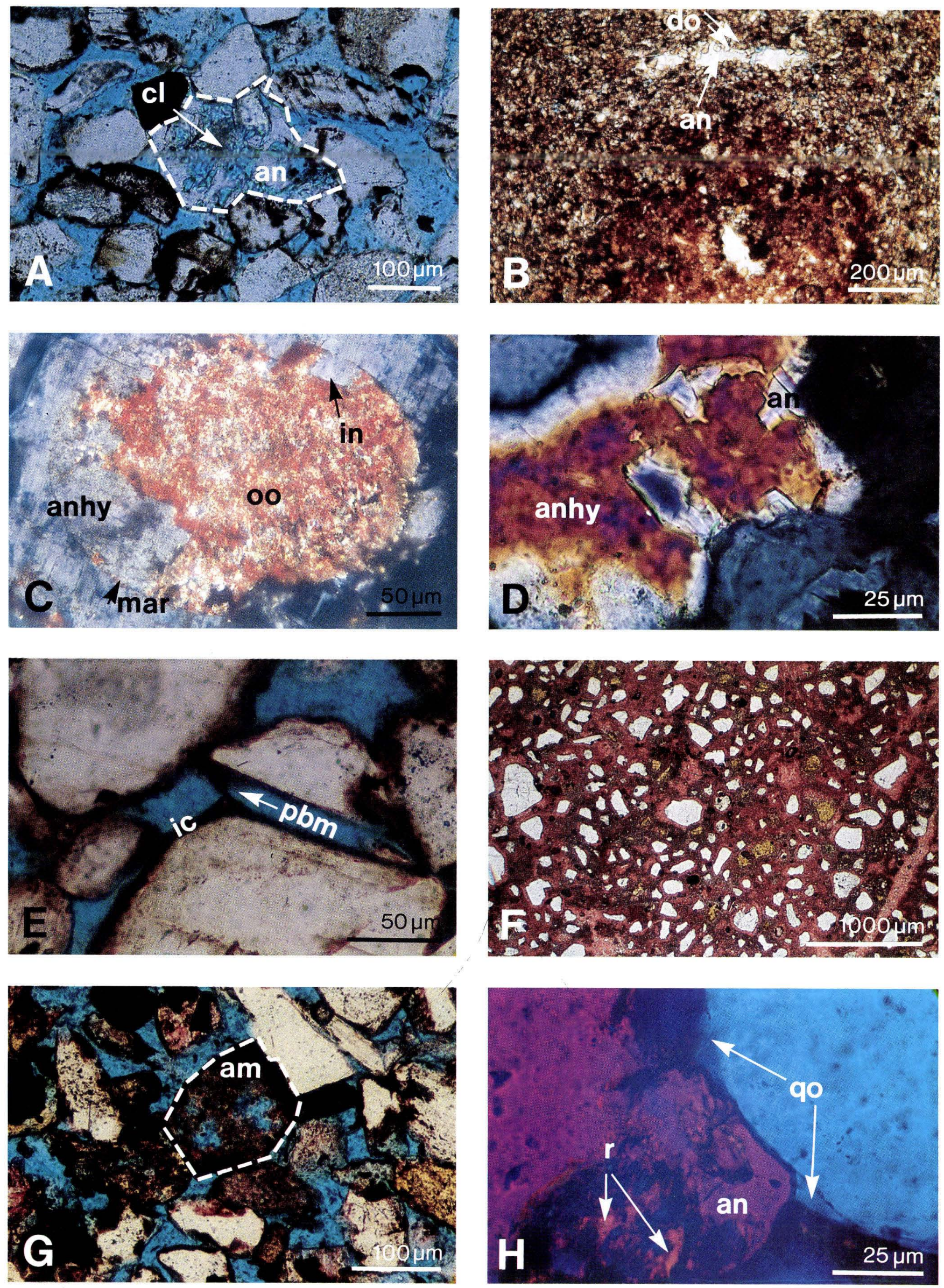


\section{PLATE 5.}

1A. Chlorite? (chl) with boxwork texture. Tønder-3, $1654.80 \mathrm{~m}$. Bar $5 \mu \mathrm{m}$.

B. Smectite? (sm) with crenulated texture. Rødby-1, $1152.07 \mathrm{~m}$. Bar $10 \mu \mathrm{m}$.

C. Vermiform kaolinite aggregate (kaol). Note possible filamentous illite/smectite (il/sm) associated with kaolinite verm. Tønder-3, $1657.00 \mathrm{~m}$. Bar $5 \mu \mathrm{m}$.

D. Pore-filling, authigenic Ti-rich mineral, probably anatase (anat). Note twinning (arrow). Tønder-3, $1671.30 \mathrm{~m}$. Bar $10 \mu \mathrm{m}$.

E. Halite (ha) covering a calcite rhomb (c). The salt is obviously an artifact, associated with drilling mud. Tønder-3, $1663.94 \mathrm{~m}$. Bar $10 \mu \mathrm{m}$. F. Primary intergranular porosity in fine-grained sandstone. Note good porosities and permeabilities. Small quartz (qo) and feldspar (fo) overgrowths are denoted by arrows. Tønder-3, $1651.03 \mathrm{~m}$. Bar $50 \mu \mathrm{m}$.

G. Second generation of quartz overgrowth (qo). Note the fresh appearance of the overgrowth compared to the altered host grain (hg), indicating that this stage of quartz authigenesis post-dated leaching. Tønder-5, $1868.66 \mathrm{~m}$. Bar $20 \mu \mathrm{m}$.

H. Illite fibers (il) encapsuled in calcite cement (c). It is not possible to state whether the illite is detrital or diagenetic. Hønning-1, $1632.95 \mathrm{~m}$. Bar $10 \mu \mathrm{m}$. 

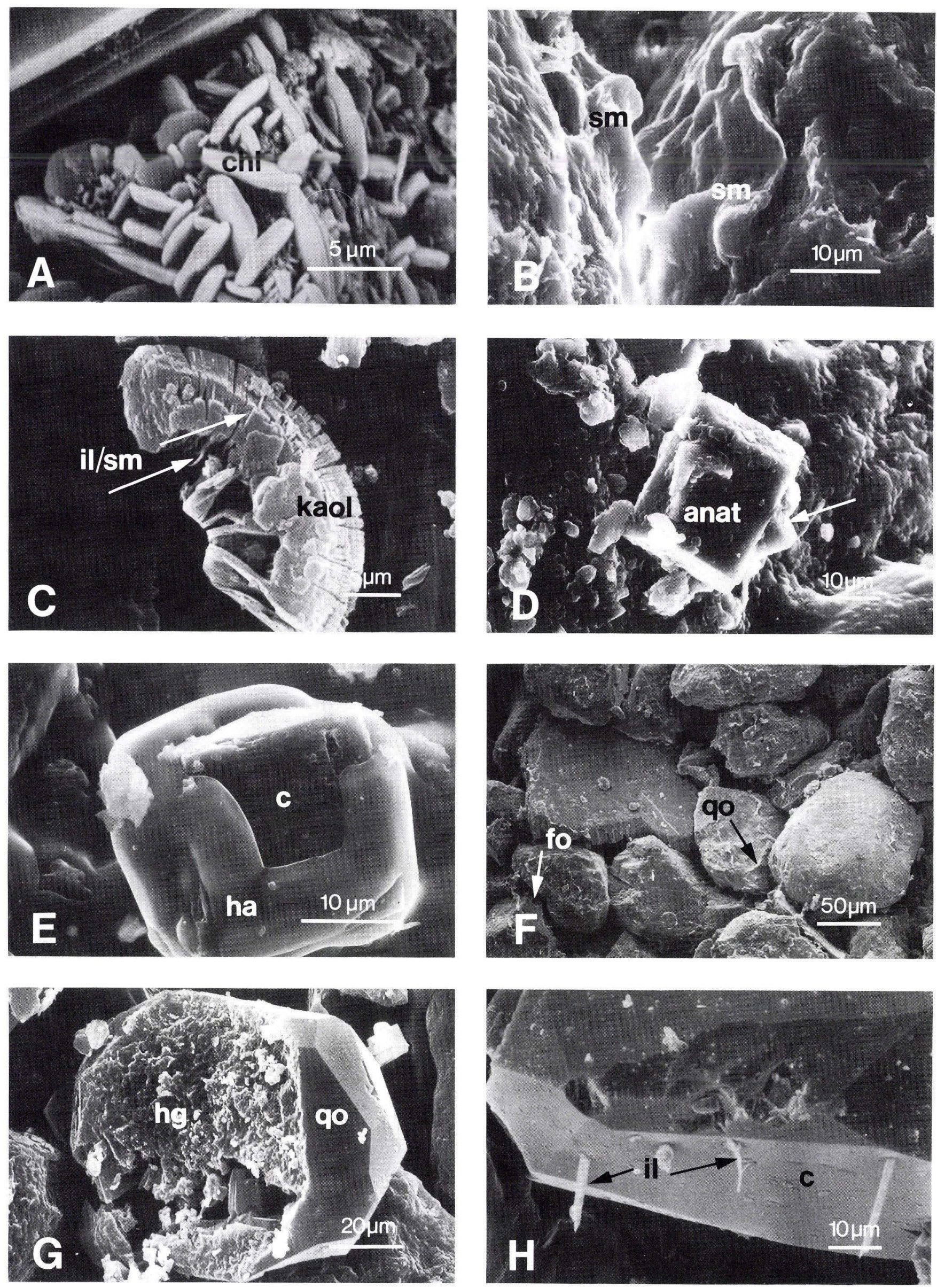
Studies have been carried out on cored material from the Lower Triassic Bunter Sandstone Formation. These redbeds were investigated by thin section, scanning electron microscopy, bulk and clay mineralogical Xray analysis and electron microprobe analysis. The data was treated by a specially developed computer program.

The project fulfilled the following objectives:

1. description of the diagenetic assemblage

2. interpretation of the diagenetic history

3. evaluation of specific influences on diagenesis by factors such as depth of burial, provenance, lithofacies and the structural and depositional settings

4. comparison with ancient and modern analogs 